http://zoobank.org/References/5D94E392-50AC-44C9-902A-F4C104BAB9E4

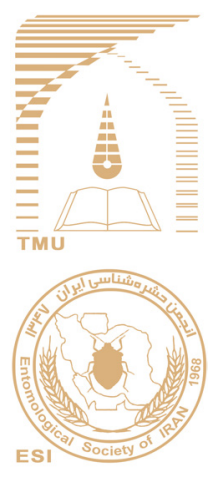

\title{
A new species and new records of Ichneumonini (Hymenoptera: Ichneumonidae, Ichneumoninae) from Iran
}

\author{
Farid Shirzadegan', Ali Asghar Talebi ${ }^{*}{ }^{*}$, Matthias Riedel ${ }^{2}$ (D) \& \\ Hamidreza Hajiqanbar1 ${ }^{10}$ \\ 1 Department of Entomology, Faculty of Agriculture, Tarbiat Modares University, Tehran, Iran. \\ f.shirzadegan@gmail.com, talebia@modares.ac.ir, hajiqanbar@modares.ac.ir \\ 2 SNSB-Zoologische Staatssammlung München, Münchenhausenstr. 21, D-81247 München, Germany. \\ mamafloriedel@t-online.de
}

A B S T R ACT . A survey was conducted on the fauna of Ichneumonini Latreille, 1802 (Ichneumonidae: Ichneumoninae) in North-central area of Iran. The specimens were collected using Malaise traps from March to November in 20102011. A total of 28 species were identified, of which three species and one subspecies are recorded for the first time from Iran: Eutanyacra ruficornis Berthoumieu, 1894; Ichneumon quadrialbatus Gravenhorst, 1820; Ichneumon sarcitorius turkestanicus Heinrich, 1929; Stenobarichneumon basalis Perkins, 1960. As well 17 species are new provincial records. A new species, Anisopygus persicus Shirzadegan, Talebi \& Riedel sp. nov. from Guilan province in northern

Received:

18 April, 2021 Iran is described and illustrated. The known number of Ichneumonini species in Iran is now raised to 143. Detailed morphological characters of the newly

Accepted:

25 July, 2021 recorded species and Virgichneumon albilineatus (Gravenhorst, 1820), as well as an updated list of the tribe Ichneumonini from Iran, are provided.

Published:

31 July, 2021

Subject Editor:

Abbas Mohammadi-

Khoramabadi

Key words: New record, New species, Ichneumoninae, Ichneumonini, Taxonomy, Checklist, Distribution, Iran

Citation: Shirzadegan, F., Talebi, A.A., Riedel, M. \& Hajiqanbar, H. (2021) A new species and new records of Ichneumonini (Hymenoptera: Ichneumonidae, Ichneumoninae) from Iran. Journal of Insect Biodiversity and Systematics, 7 (3), 287-322.

\section{Introduction}

The Ichneumonidae Latreille, 1802 represent the largest hymenopteran family with 48 generally recognized subfamilies, 1601 genera and about 25300 described species worldwide ( $\mathrm{Yu}$ et al., 2016). Ichneumoninae is the second-largest subfamily of Ichneumonidae (Burks \& Hurd, 1979) with 15 tribes (Wahl et al., 1995) and 214 genera worldwide. So far, 1300 species of this subfamily have been recorded from the Western Palaearctic region (Yu et al., 2016). Species of the tribe Ichneumonini are endoparasitoids of Lepidoptera, Coleoptera, and Hymenoptera (Jeong et al., 2009). Members of this tribe are diagnosed by the structure of the propodeum, which is of the 'broken type' and is distinctly separated on horizontal and declivous parts, meeting under an angle of carinae dentiparae

Corresponding author: Ali Asghar Talebi, E-mail: talebia@modares.ac.ir

Copyright (C) 2021, Shirzadegan et al. This is an open access article distributed under the terms of the Creative Commons NonCommercial Attribution License (CC BY NC 4.0), which permits Share - copy and redistribute the material in any medium or format, and Adapt - remix, transform, and build upon the material, under the Attribution-NonCommercial terms. 
interiors and apical carina of area superomedia. Tereshkin (2009) discussed the diagnostic characters of this tribe which are mostly based on exceptions than on characters common in all members of the taxon.

In recent years, considerable progress has been made in understanding the taxonomy and fauna of different subfamilies of Ichneumonidae in Iran (Barahoei et al., 2012, 2013, 2014a, 2014b, 2015; Mohammadi-Khoramabadi et al., 2011; 2013a, 2013b; Amiri et al., 2015a, 2015b, 2016a, 2016b, 2017; Aghadokht et al., 2017; Shirzadegan et al., 2018; Reidel et al., 2019; Zardouei Heydari et al., 2019, 2020a, 2020b,2020c, 2020d; Falahatpisheh et al., 2021). From the tribe Ichneumonini (Ichneumonidae, Ichneumoninae), 137 species have been yet recorded from Iran (Heinrich, 1929; Mojeni \& Sedivy, 2001; Kolarov \& Ghahari, 2008; Masnadi \& Jussila, 2008; Zarepour et al., 2008, 2009; Barahoei et al., 2012; Riedel et al., 2010, 2019; Riedel \& Aghadokht, 2017; Riedel, 2020).

The central north of Iran includes five provinces located on the southern and northern slopes of the Alborz Mountains, the Hyrcanian forests biome, rangelands, agricultural or residential areas. A malaise trap sampling project had been done during 2010-2011 on the species diversity of the family Ichneumonidae in this region (Mohammadi-Khoramabadi et al., 2011, 2013a, 2013b). The objective of this study is to provide new data on the tribe Ichneumonini fauna of this region of Iran.

\section{Material and methods}

Sampling was performed by using Malaise traps at different locations in Guilan province (Ghazichak, Eshman Kamachal, Orkom and Ziaz), Alborz province (Arangeh, Sarziarat, Shahrestanak and Karaj) and Tehran province (Shahriar) during March to November in 2010 and 2011 (Fig. 1). The specimens were treated with a mixture of ethanol (60\%) / xylene (40\%) for two days and with amyl acetate for the next two days (AXA) and finally placed on a filter paper for drying (van Achterberg 2009). The dried specimens were then mounted on triangular point cards. Morphological terminology follows Tereshkin (2009) and Broad et al. (2018). Relevant determination keys were used for the identification of the specimens at the species level (Rasnitsyn \& Sityan, 1981; Tereshkin, 2004, 2011). All the species were compared with the original descriptions and the specimens deposited in the Bavarian State Collection of Zoology, München, Germany. Photographs were made using either an Olympus TM AX70 microscope or an Olympus TM SZX9 stereomicroscope equipped with a Sony TM digital camera. A series of 10-15 captured images were merged into a single infocus image using the image-stacking software Zerene Stacker version 1.04. The specimens are deposited at the Collection of Department of Entomology, Tarbiat Modares University (TMUC), Tehran, Iran and the personal collection of M. Riedel (MRC).

The general abbreviations of terms used in this paper are as follows:

$\mathrm{T} 1-\mathrm{T} 7$ = first to seventh metasomal tergites

S1-S7 $=$ first to seventh metasomal sternites

$\mathrm{AOL}=$ distance between anterior ocellus and posterior ocellus

$\mathrm{OOL}=$ minimum distance between posterior ocelli and eye

$\mathrm{POL}=$ distance between two posterior ocelli. 


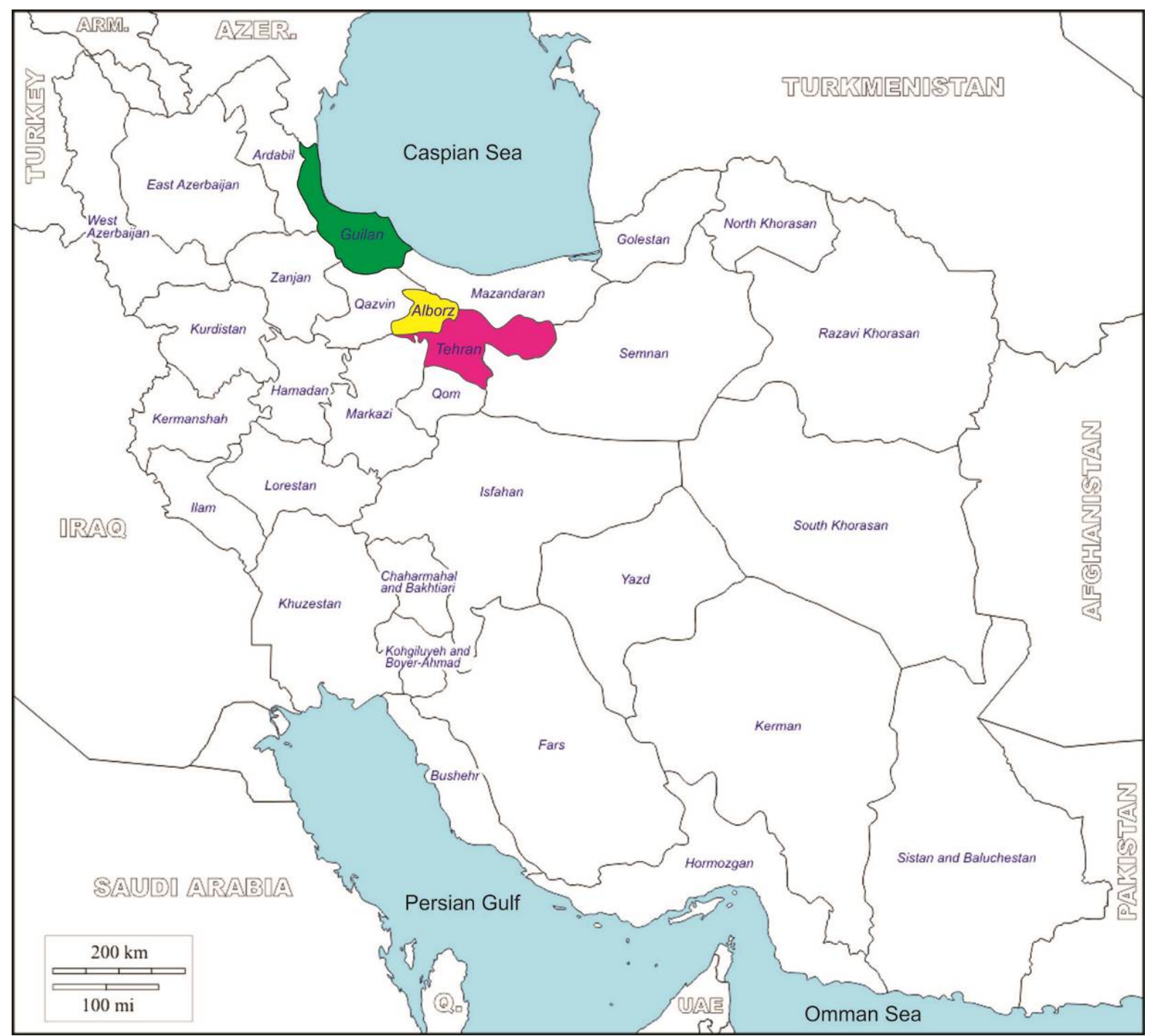

Figure 1. Map of Iran: Alborz, Tehran, Guilan provinces, where specimens have been collected in this study.

\section{Results}

Twenty-eight species belonging to thirteen genera of the tribe Ichneumonini were collected and identified. Of these, three species, Amblyteles armatorius (Forster, 1771), Vulgichneumon saturatorius (Linnaeus, 1758) and V. suavis (Gravenhorst, 1820) were previously recorded from the same provinces, 17 species are new provincial records, three species and one subspecies are new records for the Iranian fauna and one species, Anisopygus persicus Shirzadegan, Talebi and Riedel sp. nov., is newly described here.

Anisopygus persicus Shirzadegan, Talebi \& Riedel sp. nov. (Fig. 2; Figs 3A-J) http:/ / zoobank.org/F19872AC-4A5A-4A25-97D5-99C60459BAF5

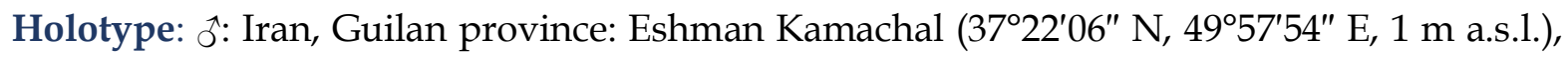
20.V.2010; TMUC, leg.: M. Khayrandish.

Paratypes: $1 \hat{\jmath}$, TMUC and $2 \hat{\jmath} \hat{0}, \mathrm{MRC}$, same data as holotype. 
Diagnosis. Anisopygus persicus sp. nov. differs from congeneric species (e.g. A. americanus Heinrich, 1961 and A. pseudonymus Wesmael, 1845 by the following combination of characters: clypeus flat (in $A$. americanus clypeus slightly convex); flagellum with white annulus on segments 9-19(20) (in A. americanus flagellum without annulus); pronotal ridge, subalarum, scutellum, postscutellum and mesopleura entirely black; all coxae and trochanters mainly black; apex of femora and tarsal segments of foreleg ivory ventrally; all tibiae with the ivory pattern, (in A. americanus the following are ivory: pronotal ridge, subalarum, scutellum, and postscutellum, sometimes prosternum, prepectus partially and small mark on the lower part of mesopleura, fore and mid coxae predominantly, the ventral apex of hind coxae, fore and mid trochanters and trochantellus ventrally, fore and mid femora, tibiae and tarsi ventrally ivory). Anisopygus persicus sp. nov. differs from $A$. pseudonymus by the following characters: temple orbits usually ferruginous marked (in $A$. pseudonymus temple orbits ivory; all coxae and trochanters mainly black (in A. pseudonymus fore coxa marked with a white spot; fore and mid legs extensively yellow); apical border of T2-T3 black (in A. pseudonymus apical border of T2 or T2-T3 usually narrowly ferruginous).

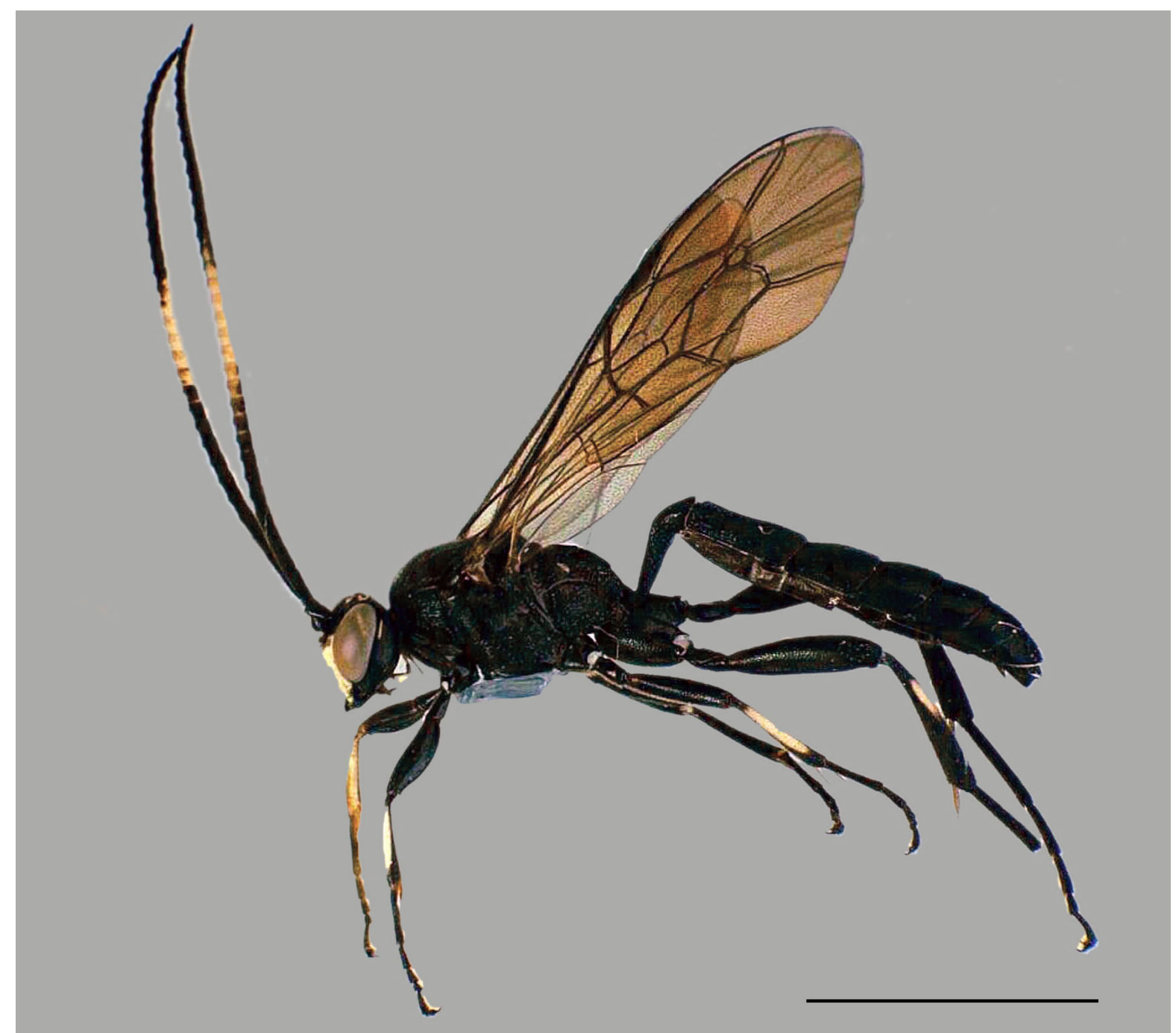

Figure 2. Lateral habitus of male in Anisopygus persicus Shirzadegan, Talebi and Riedel, sp. nov. (Scale bar: $4 \mathrm{~mm}$ ). 
Description. Length of body $12-13 \mathrm{~mm}$, antenna $11 \mathrm{~mm}$, fore wing $10 \mathrm{~mm}$, hind wing 8 $\mathrm{mm}$, hind leg $12 \mathrm{~mm}$, mesosoma $4.2 \mathrm{~mm}$, metasoma $8.5 \mathrm{~mm}$.

Head: Vertex slanting straight down after the ocelli to occipital carina in lateral view (Fig. $3 C$ ); temple $0.8 \times$ as long as transverse diameter of eye at middle, roundly narrowed behind eyes in dorsal view (Fig. 3A); occipital carina not reaching the level of hind ocelli in dorsal view; POL $1.25 \times$ as long as OOL, and 2.5 to $2.6 \times$ as long as AOL; OOL $2.0-2.1 \times$ as long as AOL; middle field of face slightly elevated, face with sparse superficial punctures, without microsculpture (Fig. 3B); clypeus $2.6 \times$ wider than its length, apical margin of clypeus straight, separated from face by slight impression; clypeus with sparse, superficial punctures, without microsculpture; malar space $0.44 \times$ basal width of mandible; occipital carina meeting hypostomal carina far from base of mandibles; mandibles strong, slightly evenly narrowed behind base, upper tooth longer than lower; antennal cavities deeply impressed, reach borders of eyes and far not reach front ocellus level, with weak tubercle between antennal fossae (Fig. 3B); margins of antennal fossae slightly elevated above face surface. Flagellum with 35 flagellomeres, with white annulus on segments (9)10-19(20), basal segment $2.6 \times$ its width at apex; with narrow tyloides on segments 5-12 (Fig. 3H).

Mesosoma (Figs 3D, 3E, 3I): Collar of pronotum in dorsal view rather long with straight front margin, transverse furrow of pronotum shallow, not interrupted by keel; pronotal ridge not swollen; epomia sharp; base of pronotum gradually curved (Fig. 3E); mesoscutum only just convex, $1.07 \times$ wider than its length; notauli in form of very slight impressions on frontal margin, middle lobe of mesoscutum densely punctured, without microsculpture, lateral lobes with sparse punctures, shining (Figs 3D); subalarum thin, sharp; axillary tongue developed, but weak; speculum with sparse superficial punctures, slightly shining (Fig. 3E); area of mesopleural fovea moderately impressed; area of mesopleural fovea slightly impressed; mesopleural suture straight, interrupted by slight transversal ribs; middle part and hind third of mesopleura wrinkly-punctured, other part of mesopleura densely punctured (Fig. 3E); sternauli not developed; scutellum convex, carinated up to middle, dorsal surface densely punctured, without microsculpture (Fig. 3I); length of horizontal part of propodeum $1.28 \times$ longer than area posteromedia in middle; carinae of propodeum sharp; area superomedia $1.25 \times$ wider than its length, costulae at middle; apices of area dentiparae slightly prominent; propodeal spiracles $2 \times$ longer than its width (Fig. 3I).

Legs: Moderately stout; densely punctured and slightly shining; hind femur $2.8 \times$ as long as its maximum width; hind tibia $1.8 \times$ longer than hind basitarsus.

Wings (Fig. 3J): Areolet pentagonal, first intercubitus (internal vein of a base or Rs) approximately equal to the length of the second intercubitus (external vein of a base or 3rs$\mathrm{m}$ ). radius (Rs) straight and slightly curved at apex; radial cell long and rather broad; ramulus distinct; all veins dark; length of fore wings $0.83 \times$ as long as the body, and $1.25 \times$ longer than hind wings.

Metasoma (Figs 3F, G): Metasoma in dorsal view elongated, parallel-sided, T2 at apex $1.2 \times$ longer than its width (Fig. 3G); middle field of postpetiole slightly elevated, $2.4 \times$ wider than lateral fields, its surface irregularly reticulate-rugose (Fig. 3F); gastrocoeli presented by shallow impressions, interspace between its irregularly wrinkled; surface of T2 reticulatecellular sculpture and T3 densely punctured; thyridia developed, interval between them wider than the middle field of postpetiole, it's surface irregularly wrinkled (Fig. 3F); lunulae only just expressed. 
Color. Body black; face and clypeus completely ivory; scape with ivory spot ventrally; scutellum black; legs black, with an ivory pattern on all tibiae; the base of all femorae brown-red.

Female. Unknown.
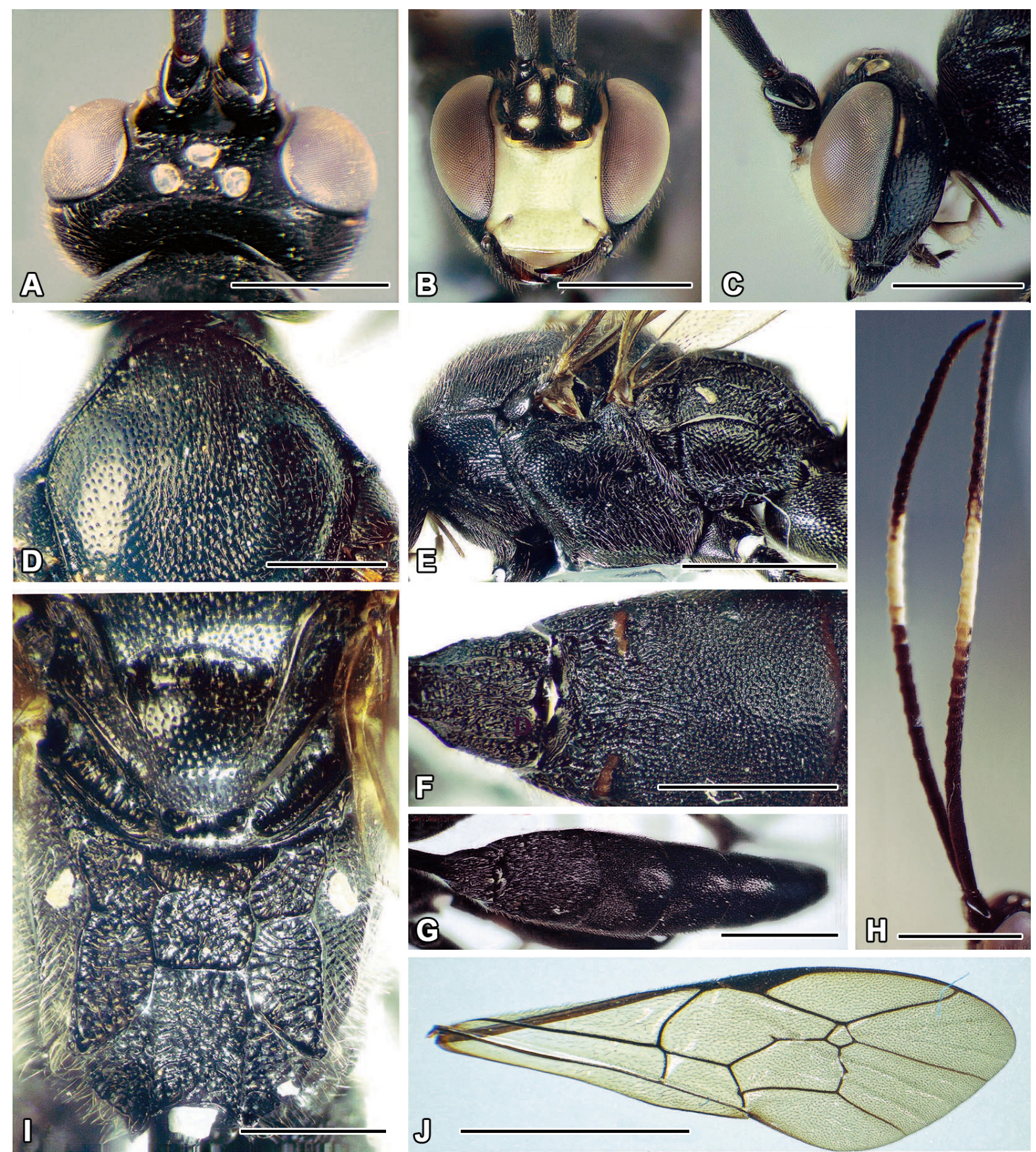

Figure 3. Anisopygus persicus Shirzadegan, Talebi and Riedel, sp. nov., male; A. Head, dorsal view, B. Head, frontal view, C. Head, lateral view, D. Mesonotum, dorsal view, E. Mesosoma, lateral view, F. T1-T2, dorsal view, G. Metasoma, dorsal view, H. Antenna, lateral view, I. Scutellum and propodeum, dorsal view, J. Fore wing. Scale bars: A-D, F, I= $1 \mathrm{~mm}, \mathrm{E}, \mathrm{G}-\mathrm{H}=2 \mathrm{~mm}, \mathrm{~J}=4 \mathrm{~mm}$. 
Hosts: Unknown.

Etymology. The name of the new species is derived from Persia, the Latin name used for the area of Iran.

General distribution. Currently, only known from the type locality in Iran.

Barichneumon chionomus (Wesmael, 1845)

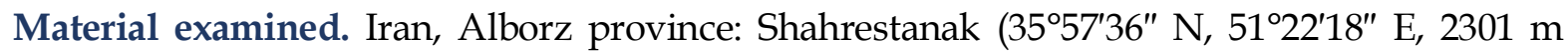

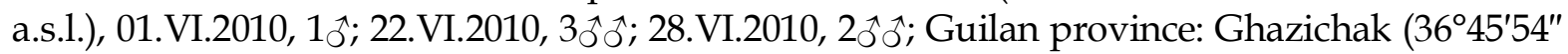

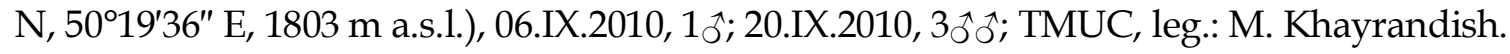

General distribution. Western and Eastern Palaearctic region (Yu et al., 2016).

Distribution in Iran. Razavi Khorasan (Ghahari \& Jussila, 2014), Alborz and Guilan (new provincial record) provinces.

Barichneumon derogator (Wesmael, 1845)

Material examined. Iran, Guilan province: Ghazichak (36²45'54" N, 50¹9'36" E, $1803 \mathrm{~m}$ a.s.1.), 05.VII.2010, 10^; TMUC, leg.: M. Khayrandish.

General distribution. Western and Eastern Palaearctic region (Yu et al., 2016).

Distribution in Iran. Fars (Falahatpisheh et al., 2021), Golestan (Aghadokht et al., 2017), Guilan (new provincial record), Kerman (Mohebban et al., 2015), Tehran (Hasanshahi et al., 2014) and Yazd (Habibi-Badrabadi et al., 2018) provinces.

Barichneumon gaullei (Berthoumieu, 1903)

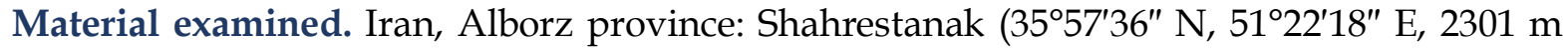

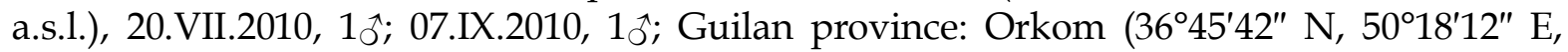
1235 m a.s.l.), 14.VI.2010, 19; TMUC, Leg.: M. Khayrandish

General distribution. Southern Europe (Yu et al., 2016).

Distribution in Iran. Kerman (Mohebban et al., 2016), Alborz and Guilan (new provincial record) provinces.

\section{Ctenichneumon castigator (Fabricius, 1793)}

Material examined. Iran, Guilan province: Orkom (36 $45^{\prime} 42^{\prime \prime} \mathrm{N}, 50^{\circ} 18^{\prime} 12^{\prime \prime} \mathrm{E}, 1235 \mathrm{~m}$ a.s.1.),

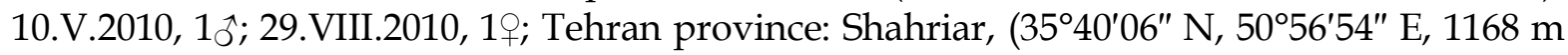
a.s.l.), 14.VII.2010, 19; TMUC, leg.: M. Khayrandish.

General distribution. Western and Eastern Palaearctic and Oriental regions (Yu et al., 2016).

Distribution in Iran. Guilan (Heinrich, 1929, current study), Mazandaran (Masnadi \& Jussila, 2008), Razavi Khorasan (Ghahari \& Jussila, 2014) and Tehran (Masnadi \& Jussila, 2008; current study) provinces.

Ctenichneumon devylderi (Holmgren, 1871)

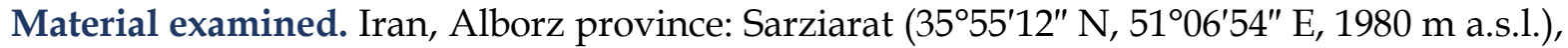

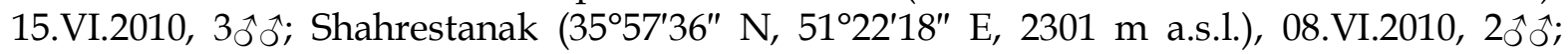
TMUC, leg.: M. Khayrandish. 
General distribution. Western and Eastern Palaearctic region (Yu et al., 2016).

Distribution in Iran. Alborz (Falahatpisheh et al., 2021; Current study), Ghom (Masnadi \& Jussila, 2008) and Kerman (Mohebban et al., 2015) provinces.

\section{Ctenichneumon inspector (Wesmael, 1845)}

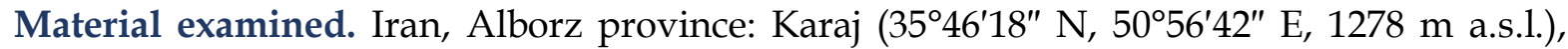

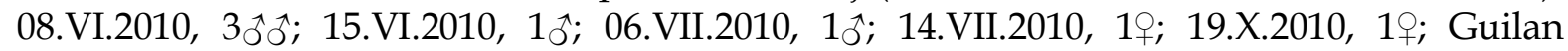
province, Ghazichak (36 $45^{\prime} 54^{\prime \prime} \mathrm{N}, 50^{\circ} 19^{\prime} 36^{\prime \prime}$ E, $1803 \mathrm{~m}$ a.s.1.), 05.VII.2010, 1웅 09.VIII.2010,

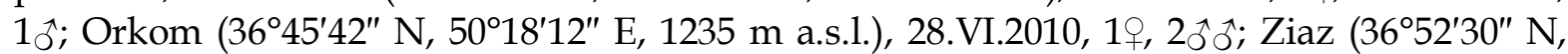

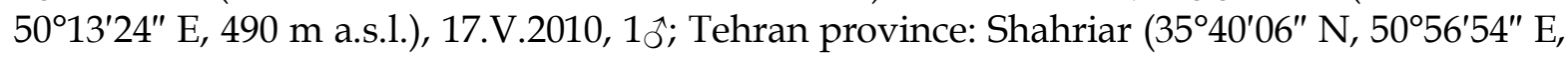

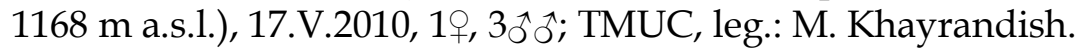

General distribution. Western and Eastern Palaearctic, Oriental regions (Yu et al., 2016).

Distribution in Iran. Alborz, Guilan and Tehran provinces (new provincial record). This species was previously reported from Iran (Tehran province), which is excluded from the current list of valid records because it has been published in an invalid journal.

\section{Ctenichneumon panzeri (Wesmael, 1845)}

Material examined. Iran, Guilan province: Orkom (36 $45^{\prime} 42^{\prime \prime} \mathrm{N}, 50^{\circ} 18^{\prime} 12^{\prime \prime}$ E, $1235 \mathrm{~m}$ a.s.l.), 10.V.2010, 10;; TMUC, Leg.: M. Khayrandish.

General distribution. Australasian, Oriental, Western and Eastern Palaearctic regions ( $\mathrm{Yu}$ et al., 2016).

Distribution in Iran. Golestan (Heinrich, 1929; Ghadiri et al., 2007), Guilan (new provincial record), Mazandaran (Masnadi \& Jussila, 2008), Sistan and Baluchestan (Kolarov \& Ghahari, 2008) and Razavi Khorasan (Ghahari \& Jussila, 2014) provinces.

\section{Ctenichneumon repentinus (Gravenhorst, 1820)}

Material examined. Iran, Alborz province, Karaj (3546'18" N, 50 $56^{\prime} 42^{\prime \prime}$ E, $1278 \mathrm{~m}$ a.s.l.),

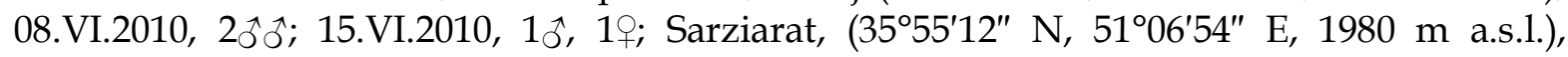
15.VI.2010, 10; Guilan province, Ghazichak (36 $45^{\prime} 54^{\prime \prime} \mathrm{N}, 50^{\circ} 19^{\prime} 36^{\prime \prime} \mathrm{E}, 1803 \mathrm{~m}$ a.s.l.), 26.VII.2010, 10’; Tehran province: Shahriar $\left(35^{\circ} 40^{\prime} 06^{\prime \prime} \mathrm{N}, 50^{\circ} 56^{\prime} 54^{\prime \prime} \mathrm{E}, 1168 \mathrm{~m}\right.$ a.s.l.), 29.VI.2010, 20ิ龴; TMUC, leg.: M. Khayrandish.

General distribution. Western and Eastern Palaearctic region (Yu et al., 2016).

Distribution in Iran. Alborz, Guilan, Tehran (new provincial record), East and West Azarbaijan (Kolarov \& Ghahari, 2008) provinces.

\section{Diphyus ochromelas (Gmelin, 1790)}

Material examined. Iran, Guilan province: Ghazichak (364 $45^{\prime} 54^{\prime \prime}$ N, 50²19'36" E, $1803 \mathrm{~m}$ a.s.1.), 07.VI.2010, 10; TMUC, leg.: M. Khayrandish.

General distribution. Western and Eastern Palaearctic region (Yu et al., 2016).

Distribution in Iran. Ardabil (Kolarov \& Ghahari, 2008; Masnadi \& Jussila, 2008) and Guilan (new provincial record) provinces. 


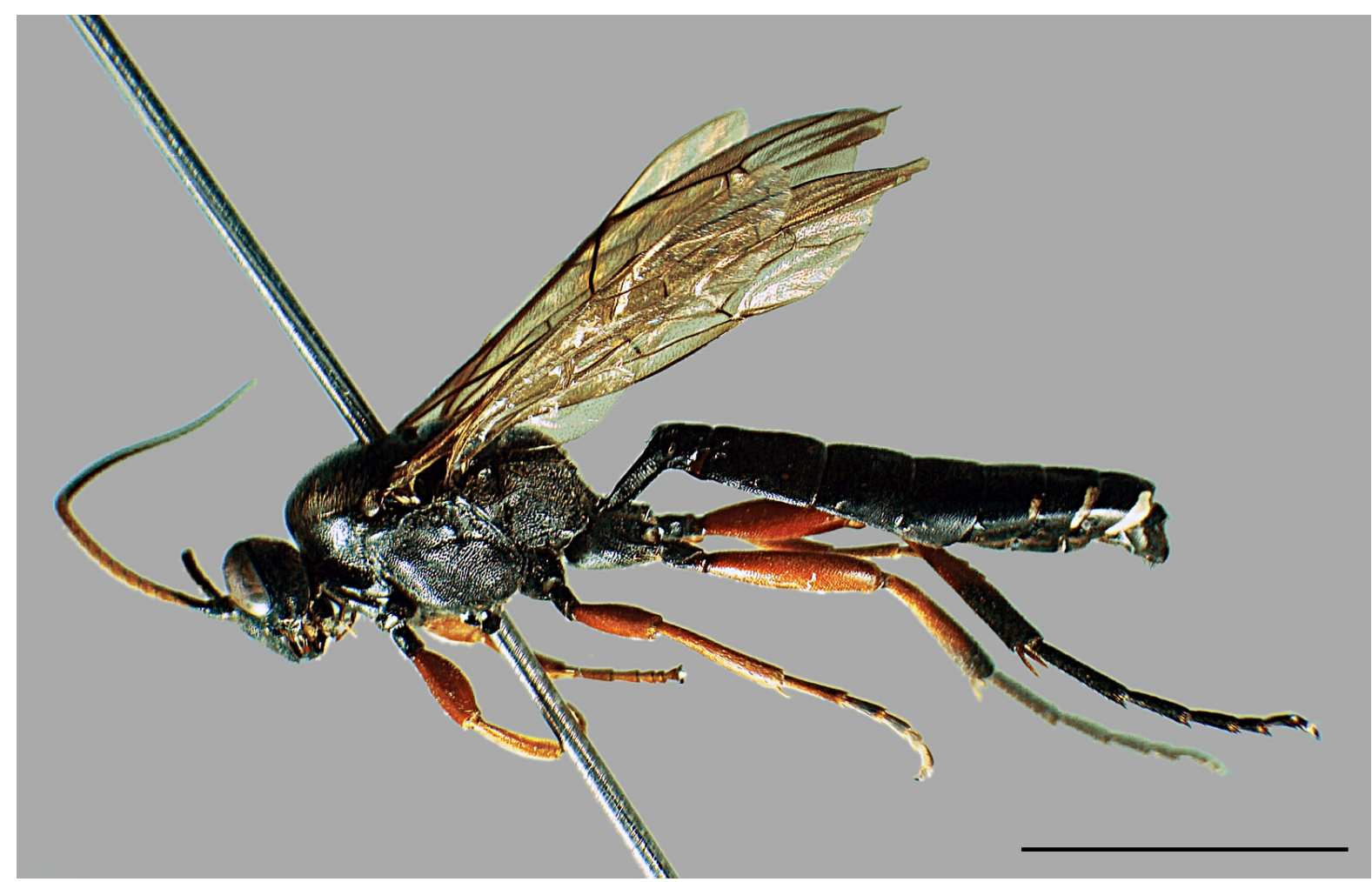

Figure 4. Lateral habitus of male in Eutanyacra ruficornis Berthoumieu, 1894 (scale bar: 5mm).

\section{Eutanyacra ruficornis (Berthoumieu, 1894) (Fig. 4; Figs 5A-G)}

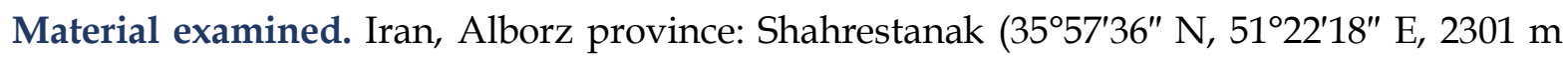
a.s.1.), 20.VII.2010, 10; TMUC, leg.: M. Khayrandish.

Diagnostic characters (male). Body length $16 \mathrm{~mm}$; Vertex linearly sloping from ocelli to occipital carina in lateral view (Fig. 5C); temples equal to transverse diameter of eye at middle, behind eyes slightly roundly narrowed in dorsal view (Fig. 5A); occipital carina from above not reaching level of eyes and hind ocelli; middle field of face slightly elevated, its surface densely punctured (Fig. 5B); clypeus $2.5 \times$ wider than length, apical margin of clypeus straight, separated from face by slight impression; clypeus densely punctured (Fig. 5B); malar space $0.66 \times$ basal width of mandible; occipital carina meeting hypostomal carina some before base of mandibles; mandibles narrow, gradually narrowed towards apex, upper tooth distinctly longer than lower; antennal cavities strongly impressed, reach borders of eyes and almost reach front ocellus level, with tubercle between antennal fossae; margins of antennal fossae high elevated above face surface (Fig. 5B); flagellum with 41 segments, with long row of long tyloides on segments $2-19$, basal segment in dorsal view 3 $\times$ longer than its width at apex; collar of pronotum from above long, with straight front margin; mesoscutum slightly convex, with equal length and breadth; notauli in form of very slight frontal impressions; mesopleura very densely punctured, without microsculpture; speculum densely punctured; mesopleural fovea small, area of mesopleural fovea only just impressed; subalarum moderately thick (Fig. 5D); sternauli absent; scutellum high elevated, laterally not carinated (Fig. 5E); carinae of propodeum sharp, costulae absent; area superomedia $2.3 \times$ wider than its length; area dentiparae at apices with slight denticles (Fig. 5E); propodeal spiracles long, slit-shaped, $4 \times$ longer than its width; T2 
transversal, $1.55 \times$ wider than its length at apex; middle field of postpetiole $2.13 \times$ wider than lateral fields, its surface longitudinally-wrinkled (striated) (Fig. 5F); gastrocoeli comparatively short, deep, narrower than interval between them; thyridiae not developed; lunulae distinct, of moderate size (Fig. 5F); S2 and S3 with fold; hypopygium with long, sharpened and compressed from sides median process.

Coloration. Head and thorax completely black; basal flagellomeres reddish; scutellum, coxae, trochanters of all legs, the apex of hind tibiae and tarsi black; T5-T7 with short ivory posterolateral stripes.

General distribution. Algeria, Turkey (Yu et al., 2016) and Iran (new record).

Distribution in Iran. Alborz province.
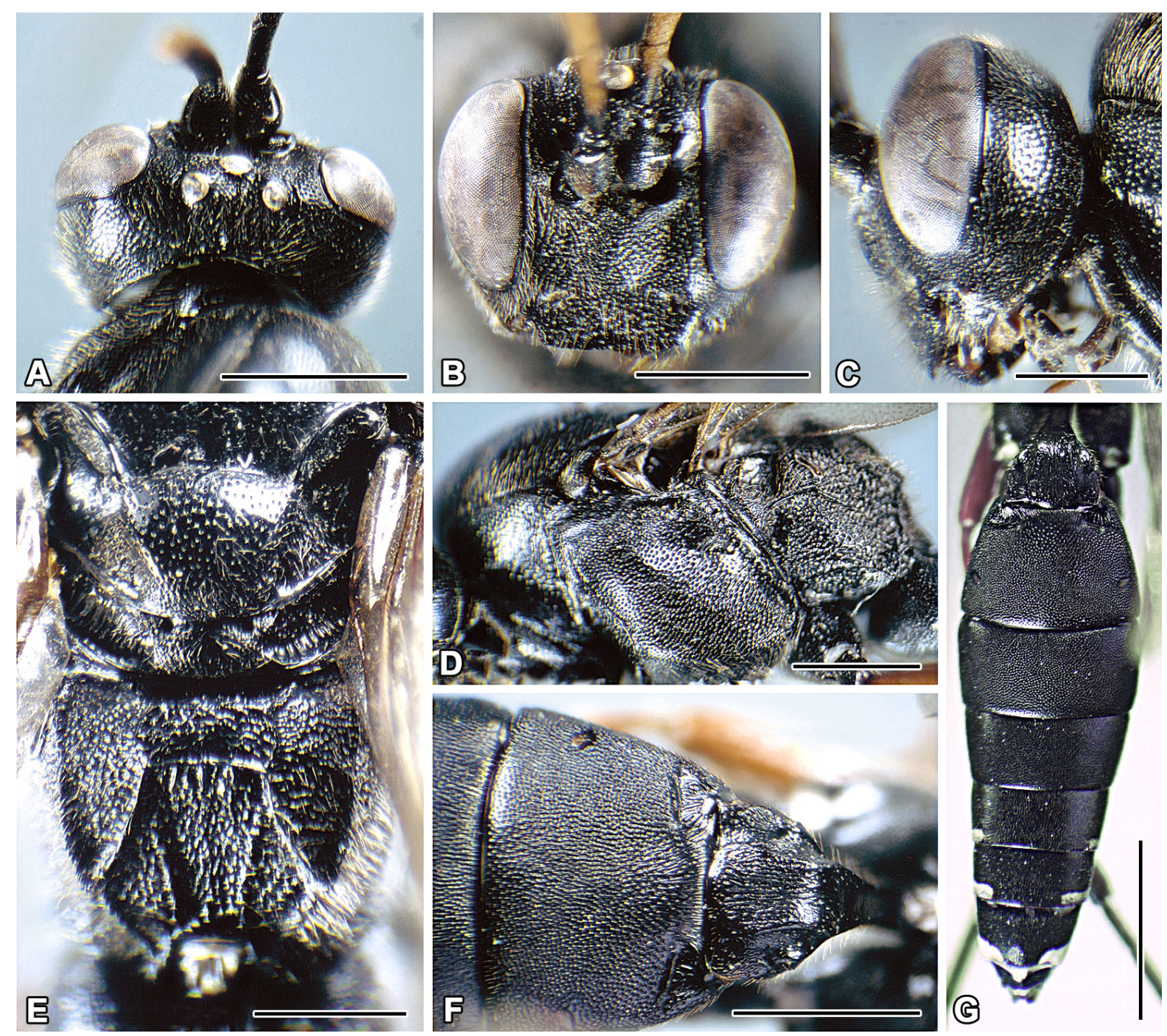

Figure 5. Eutanyacra ruficornis Berthoumieu, 1894, male; A. Head, dorsal view, B. Head, frontal view, C. Head, lateral view, D. Mesosoma, lateral view, E. Scutellum and propodeum, dorsal view, F. T1-T2, dorsal view, G. Metasoma, dorsal view. Scale bars: A= $1.5 \mathrm{~mm}, \mathrm{~B}-\mathrm{E}=$ $1 \mathrm{~mm}, \mathrm{~F}=2 \mathrm{~mm}, \mathrm{G}=3 \mathrm{~mm}$. 


\section{Ichneumon proletarius (Wesmael, 1848)}

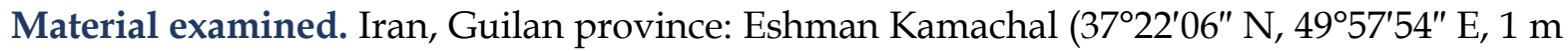

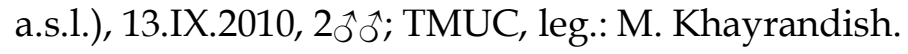

General distribution. Western and Eastern Palaearctic region (Selfa, 1996; Yu et al., 2016).

Distribution in Iran. Golestan (Heinrich, 1929), Sistan and Baluchestan (Kolarov \& Ghahari, 2008), Tehran (Masnadi \& Jussila, 2008) and Guilan (new provincial record) provinces.

\section{Ichneumon quadrialbatus (Gravenhorst, 1820) (Fig. 6; Figs 7A-F)}

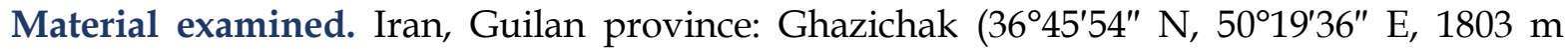
a.s.l.), 06.VI.2010, 19; TMUC, leg.: M. Khayrandish.

Diagnostic characters (female). Body length $15 \mathrm{~mm}$ (Fig. 6); Vertex straightly slanting down after the ocelli to occipital carina in lateral view (Fig. 7B); temples $1.07 \times$ transverse diameter of eye at middle, behind eyes straightly narrowed in dorsal view; temples wrinkly-punctured (Fig. 7B); face $2.75 \times$ wider than length, middle field slightly elevated, its surface wrinkly-punctured; clypeus $2.5 \times$ wider than length, apical margin of clypeus straight, separated from face by slight impression; surface of clypeus densely punctured (Fig. 7A); malar space $1.46 \times$ basal width of mandible; occipital carina meeting hypostomal carina far from base of mandibles; mandibles long, gradually narrowed towards apex, upper tooth distinctly longer than lower; antennal cavities moderately deep, reach borders of eyes and far not reach front ocellus level, with weak tubercle between antennal fossae; margins of antennal fossae slightly elevated above face surface (Fig. 7A); flagellum with 39 segments and with testaceous annulus on segments (9)10-12, basal segment from the side $2.55 \times$ longer than its width at apex; mesoscutum only just convex, of equal length and breadth; notauli in form of very slight impressions at base of mesoscutum; surface of mesopleura densely punctured (Fig. 7C); subalarum narrow, but not sharpened (Fig. 7C); sternauli not expressed; scutellum slightly elevated, laterally not carinated (Fig. 7D); costulae absent; area superomedia $1.25 \times$ wider than long (Fig. 7D); propodeal spiracle $2.8 \times$ longer than its width; carina of area posteromedia absent; T2 almost $1.27 \times$ wider than its length at apex; middle field of postpetiole slightly elevated, its surface regularly longitudinally wrinkled (striated) (Fig. 7E); gastrocoeli distinct, moderately deep, oblique; thyridia distinct, $0.83 \times$ narrower than interval between them (Fig. 7E).

Coloration. Head and thorax black; legs with exception of coxae and trochanters testaceous; tergites of metasoma with exception of T2 and T3 completely black; T6 and T7 of metasoma with central ivory spot.

General distribution. Western and Eastern Palaearctic regions (Yu et al., 2016) and Iran (new record).

Distribution in Iran. Guilan province. 


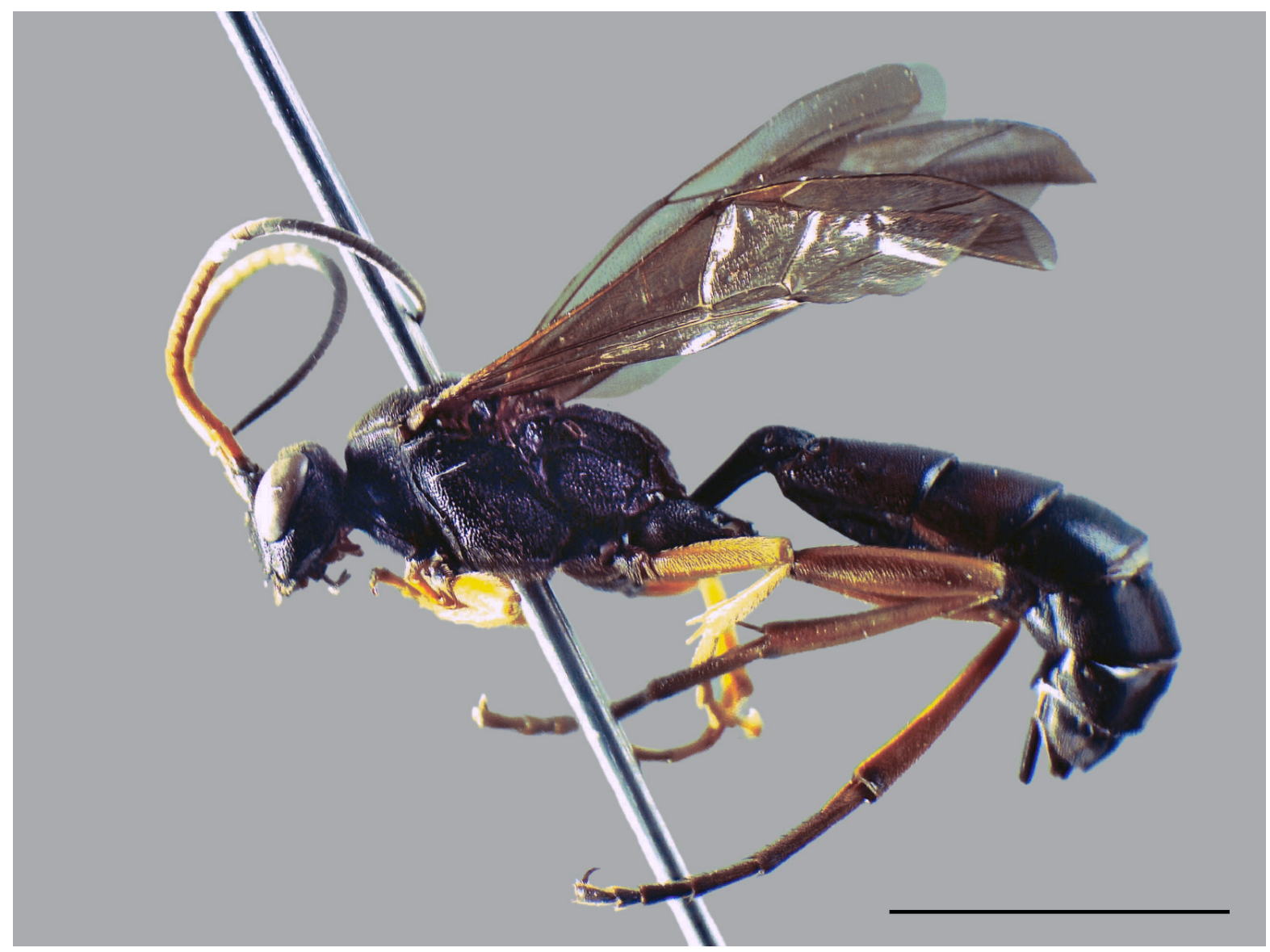

Figure 6. Lateral habitus of female in Ichneumon quadrialbatus Gravenhorst, 1820 (scale bar: 4 $\mathrm{mm})$.

\section{Ichneumon sarcitorius turkestanicus (Heinrich, 1929) (Fig. 8; Figs 9A-I)}

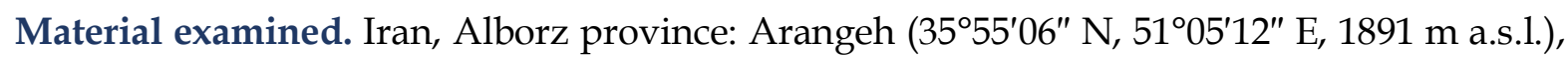

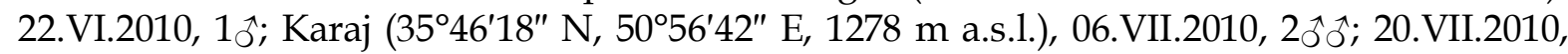

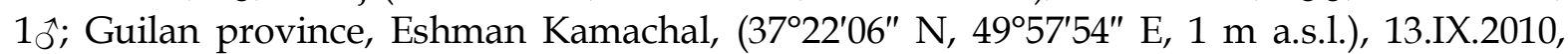

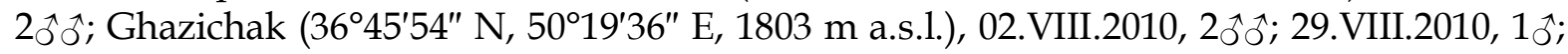

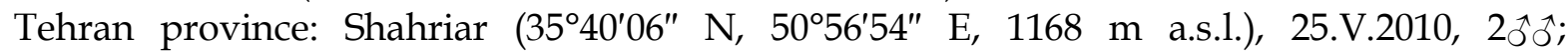

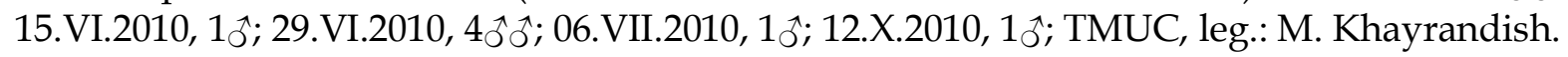

Diagnostic characters (male). Body length 14-15 mm (Fig. 8); vertex straightly slanting down after the ocelli to occipital carina in lateral view (Fig. 9C); temples shorter than transverse diameter of eye at middle, parallel to hind margin of eye, behind eyes sharply and straightly narrowed in dorsal view (Fig. 9A); temples densely punctured by superficial punctures (Fig. 9C); occipital carina from above not reach level of eyes and hind ocelli; middle field of face slightly elevated, its surface densely punctured; surface of lateral fields of face with sparse, superficial punctures, without microsculpture (Fig. 9B); clypeus $4.7 \times$ wider than length, apical margin of clypeus straight, separated from face by slight impression; clypeus with big, sparse, superficial punctures, without microsculpture (Fig. 9B); malar space $0.62 \times$ basal width of mandible; hypostomal carina not visible in lateral view, occipital carina meeting hypostomal carina far from base of mandibles (Fig. 9C); 
mandibles long, gradually narrowed towards apex, upper tooth distinctly longer than lower; antennal cavities deeply impressed, reach borders of eyes and far not reach front ocellus level, with weak tubercle between antennal fossae; margins of antennal fossae slightly elevated above face surface (Fig. 9B); flagellum with 38 segments and without annulus on segments, length of basal segment $1.8 \times$ its width at apex; transverse furrow of pronotum shallow, not interrupted by keel; mesoscutum only just convex, $1.06 \times$ longer than its width (Fig. 9D); notauli in form of very slight impressions at base of mesoscutum; mesopleura very densely punctured, without microsculpture (Fig. 9E); speculum with sparse superficial punctures (Fig. 9E); sternauli in a form of indistinct impressions in front third; scutellum flat, laterally not carinated (Fig. 9H); carinae of propodeum sharp, costulae present; area superomedia large, rectangular, $1.66 \times$ wider than its length; area dentiparae at apices without apophyses and teeth (Fig. $9 \mathrm{H})$; propodeal spiracles $3.5 \times$ longer than wide; T2 transversal, $1.2 \times$ wider than long at apex; middle field of postpetiole slightly elevated, $1.66 \times$ wider than lateral fields, its surface regularly longitudinally wrinkled (striated) without microsculpture (Fig. 9I); gastrocoeli distinct, moderately deep, oblique; thyridia developed, interval between them wider than middle field of postpetiole (Fig. 9I).

Coloration. Hind femur and tibia yellow, conspicuously black apically; T1 often yellowmarked apically; T2-T3 black, yellow apically, both tergites with the yellow apical margin broader laterally than centrally; T4 often yellow apically at least laterally; T5 black; T6-T7 dorsally, apically yellow.

General distribution. Uzbekistan (Yu et al., 2016) and Iran (new record).

Distribution in Iran. Alborz, Guilan and Tehran provinces.

Probolus crassulus (Horstmann, 2000)

Material examined. Iran, Guilan province: Orkom (36 $45^{\prime} 42^{\prime \prime} \mathrm{N}, 50^{\circ} 18^{\prime} 12^{\prime \prime} \mathrm{E}, 1235 \mathrm{~m}$ a.s.l.),

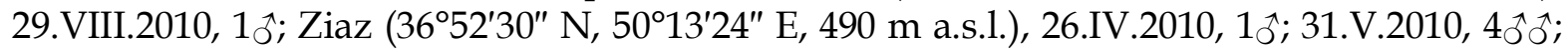
05.VII.2010, 10^; 19.VII.2010, 10^; TMUC, Leg.: M. Khayrandish.

General distribution. Western and Eastern Palaearctic region (Yu et al., 2016).

Distribution in Iran. Lorestan (Ghahari \& Gadalla, 2015) and Guilan (new provincial record) provinces.

Probolus culpatorius (Linnaeus, 1758)

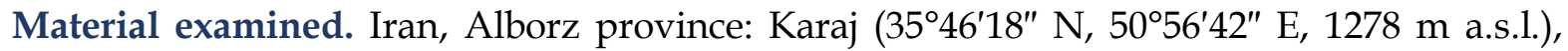
28.VII.2010, 20ิ ô; Guilan province, Ziaz (3652'30" N, 50¹3'24" E, 490 m a.s.1.), 07.VI.2010, 1今; TMUC, Leg.: M. Khayrandish.

General distribution. Western and Eastern Palaearctic region (Yu et al., 2016).

Distribution in Iran. Golestan (Masnadi \& Jussila, 2008), Alborz and Guilan (new provincial record) provinces.

Pseudoamblyteles homocerus (Wesmael, 1845)

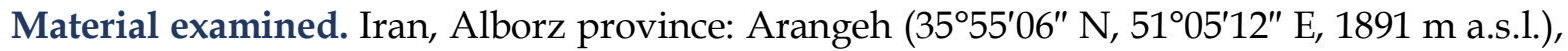
01.VI.2010, 2o+; TMUC, leg.: M. Khayrandish.

General distribution. Eastern and Western Palaearctic, Nearctic (Selfa, 1996; Yu et al., 2016). 
Distribution in Iran. Alborz (new provincial record), Kerman (Mahyabadi et al., 2018) Razavi Khorasan (Barahoei et al., 2012, 2014b), Qazvin (Ghahari \& Schwarz, 2012) and Sistan and Baluchestan (Hedwig, 1957) provinces.
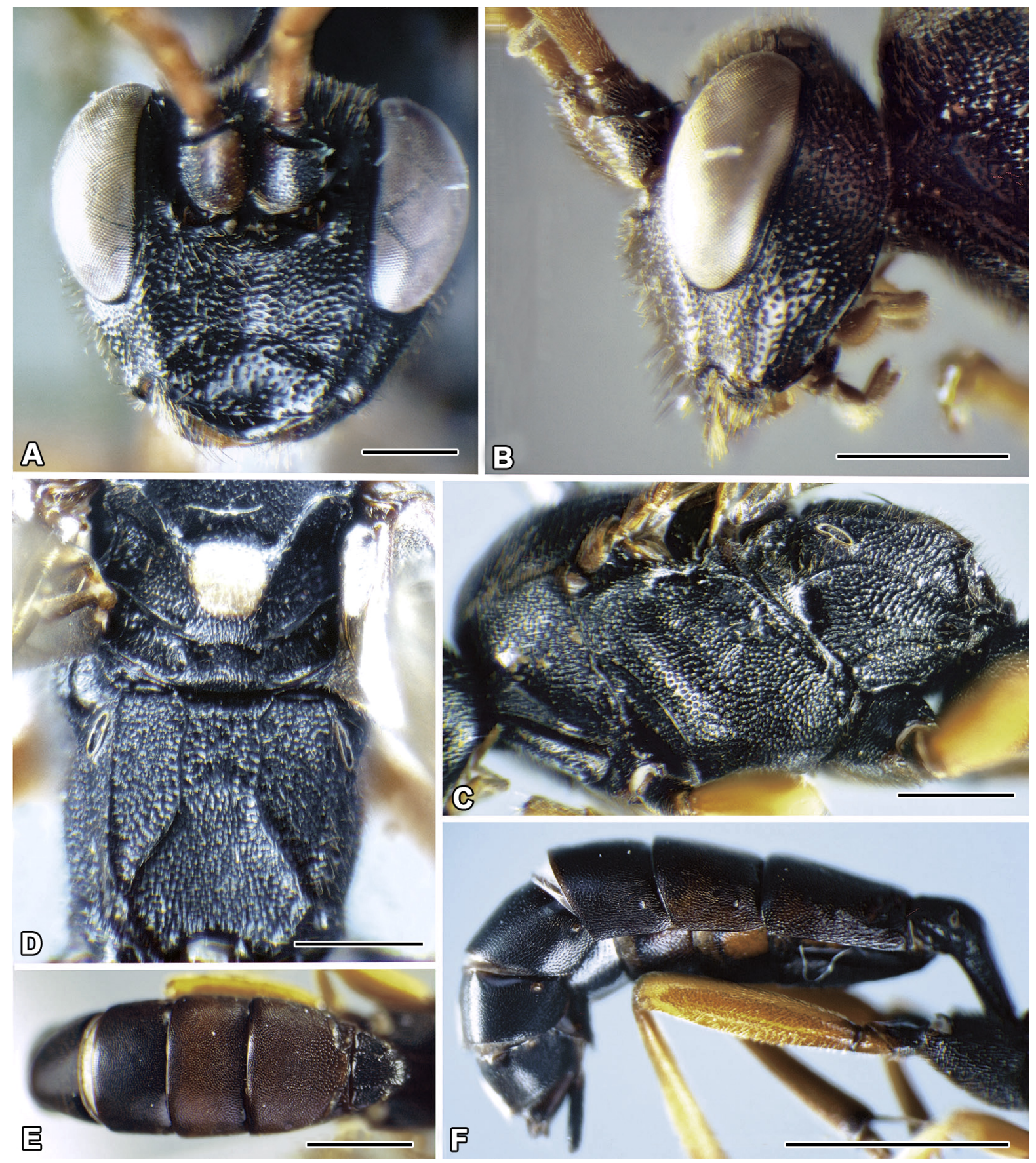

Figure 7. Ichneumon quadrialbatus Gravenhorst, 1820, male; A. Head, frontal view, B. Head, lateral view, C. Mesosoma, lateral view, D. Scutellum and propodeum, dorsal view, E. Metasoma, dorsal view, $F$. Metasoma, lateral view (scale bars: $A=0.5 \mathrm{~mm}, \mathrm{~B}-\mathrm{D}=1 \mathrm{~mm} ., \mathrm{E}=$ $2 \mathrm{~mm}, \mathrm{~F}=3 \mathrm{~mm}$ ). 


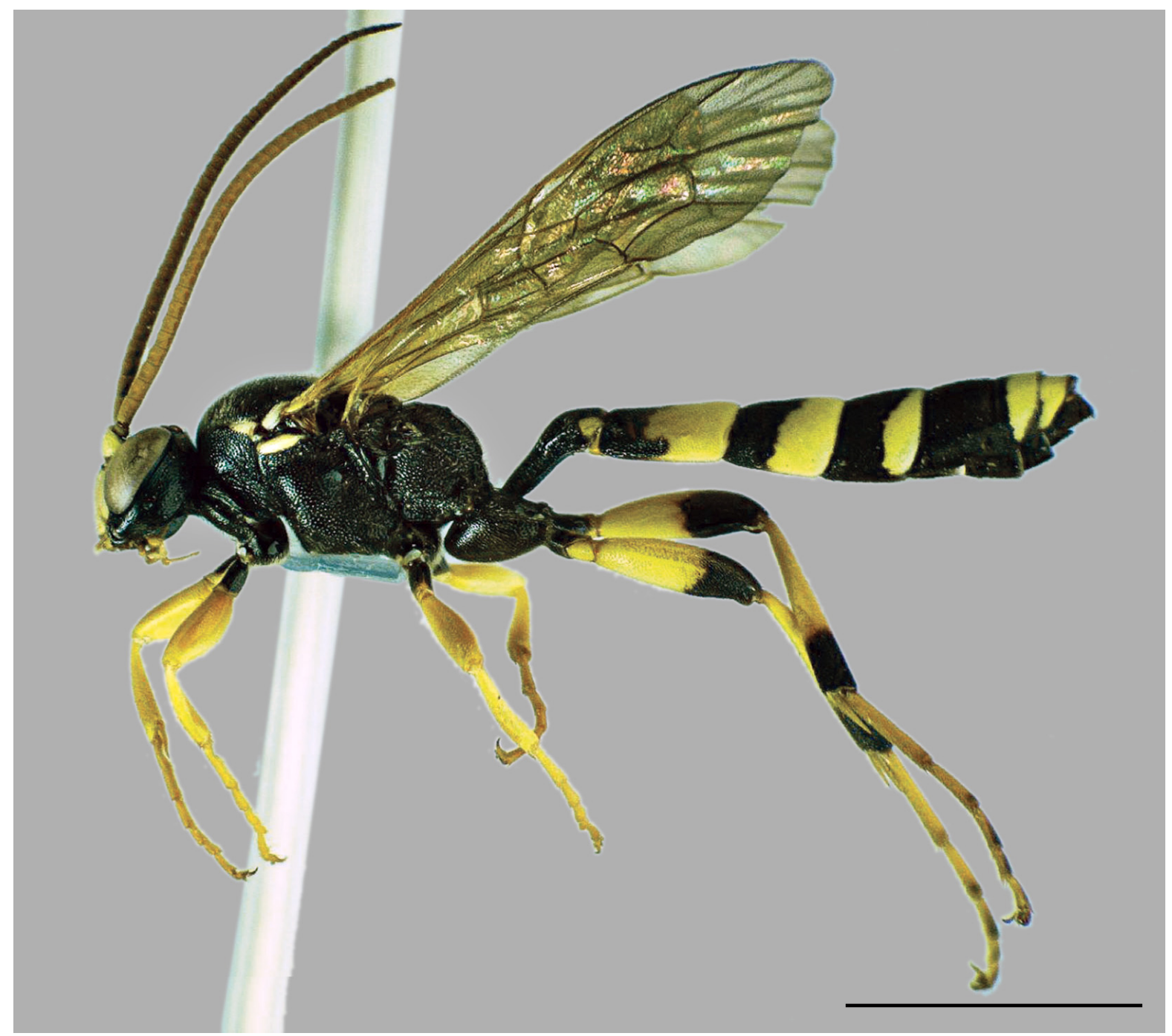

Figure 8. Lateral habitus of male in Ichneumon sarcitorius turkestanicus (Heinrich, 1929) (scale bar $=4 \mathrm{~mm})$.

\section{Spilothyrateles illuminatorius (Gravenhorst, 1820)}

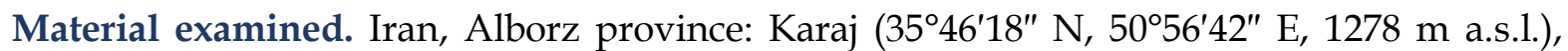
12.X.2010, 19; Guilan province: Ghazichak $\left(36^{\circ} 45^{\prime} 54^{\prime \prime} \mathrm{N}, 50^{\circ} 19^{\prime} 36^{\prime \prime} \mathrm{E}, 1803 \mathrm{~m}\right.$ a.s.l.),

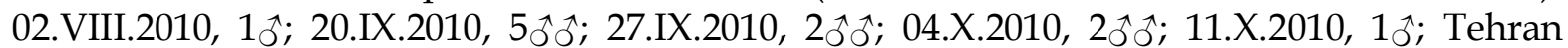

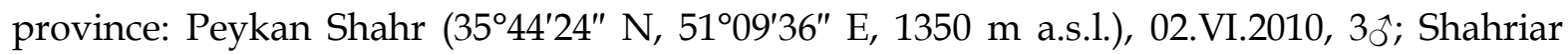

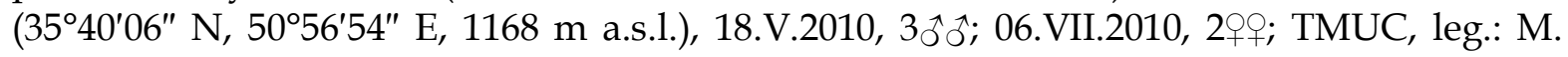
Khayrandish.

General distribution. Western and Eastern Palaearctic region (Yu et al., 2016).

Distribution in Iran. Alborz and Tehran (new provincial record), Kerman (Mohebban et al., 2016), Mazandaran (Kolarov \& Ghahari, 2008) provinces. 


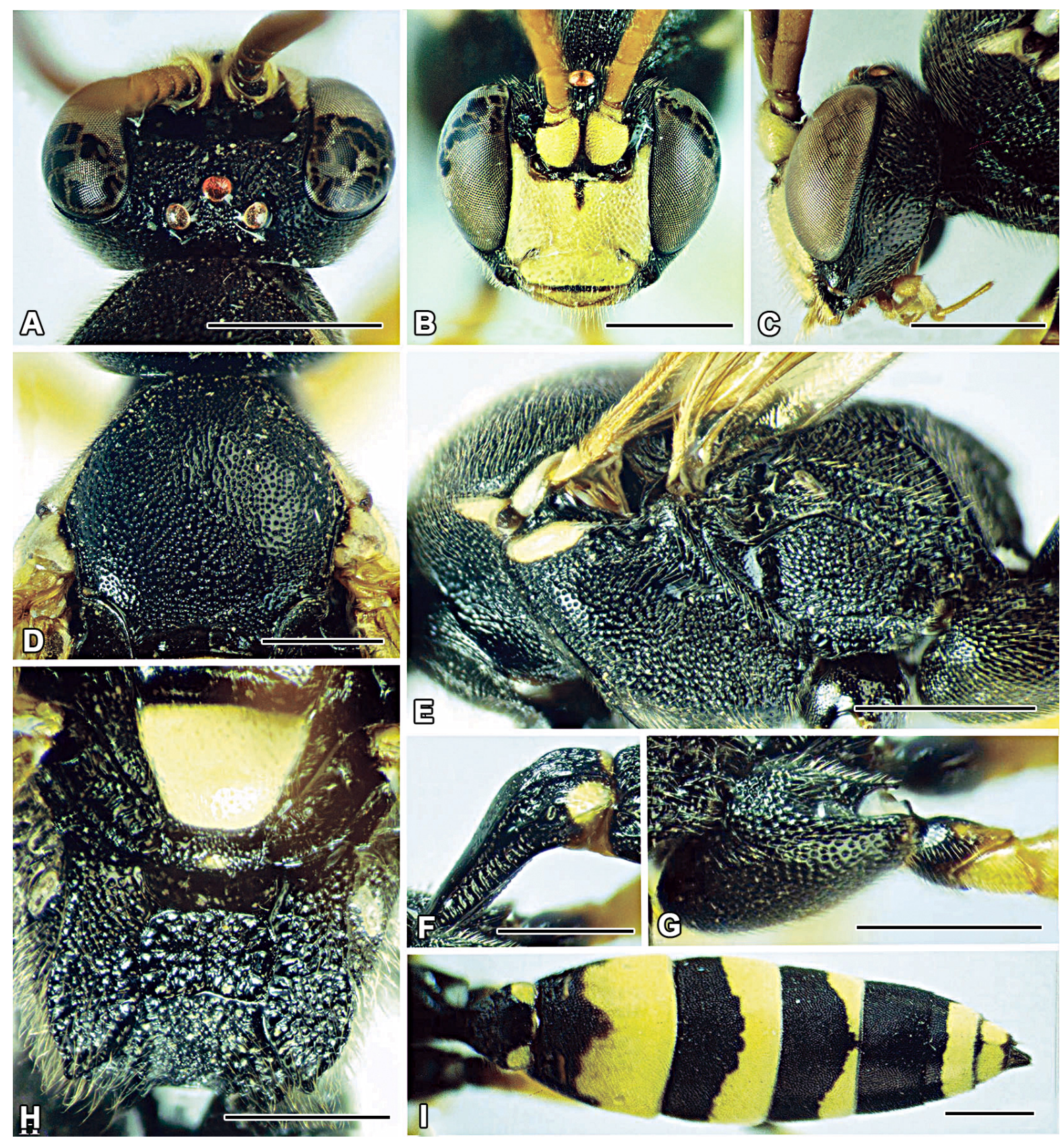

Figure 9. Ichneumon sarcitorius turkestanicus (Heinrich, 1929), male; A. Head, dorsal view, B. Head, frontal view, C. Head, lateral view, D. Mesonotum, dorsal view, E. Mesosoma, lateral view, F. T1, lateral view, G. Hind coxa and trochanter, lateral view, H. Scutellum and propodeum, dorsal view, I. Metasoma, dorsal view. All scale bars $=1 \mathrm{~mm}$.

Spilothyrateles nuptatorius (Fabricius, 1793)

Material examined. Iran, Alborz province: Karaj (3546'18" N, 5056'42" E, 1278 m a.s.l.),

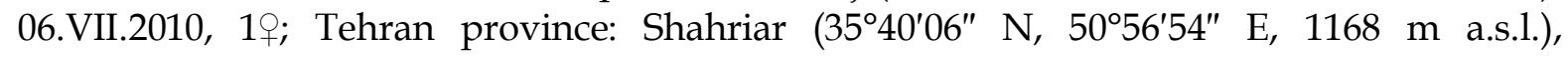
15.VI.2010, 2o+; TMUC, leg.: M. Khayrandish.

General distribution. Western and Eastern Palaearctic region (Yu et al., 2016). 
Distribution in Iran. Alborz, Tehran (new provincial record), Golestan (Heinrich, 1929; Aghadokht et al., 2017) and Isfahan (Barahoei et al., 2014a, 2015) provinces.

Remark. This species has previously been recorded as Anisobas australis Habermehl, 1917 (Heinrich, 1929) from Iran, which is a synonym of Spilothyrateles nuptatorius.

\section{Stenobarichneumon basalis (Perkins, 1960) (Fig. 10; Figs 11A-H)}

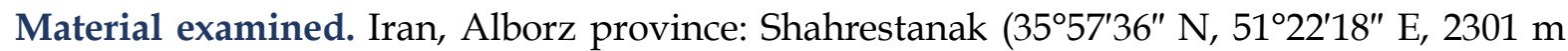
a.s.1.), 06.VII.2010, 10; 14.VII.2010, 10, TMUC, leg.: M. Khayrandish.

Diagnostic characters (male). Body length 7-7.5 mm (Fig. 10); Vertex straightly slanting down to occipital carina in lateral view (Fig. 11C); temples slightly roundly narrowed behind eyes in dorsal view (Fig. 11A); middle field of face slightly elevated; clypeus flat, 2.5 $\times$ wider than height, only just visible separated from face, with sparse, superficial punctures, without microsculpture (Fig. 11B); malar space $0.44 \times$ basal width of mandible; antennal cavities moderately deep (Fig. 11B); antenna with 28 flagellomeres, with narrow tyloides on segments $4-11$, basal segment from the side $2.6 \times$ longer than width at apex; mesoscutum moderately convex, of equal length and breadth; notauli developed in front third (Fig. 11D); surface of mesopleura shining, densely punctured; area of mesopleural fovea slightly Impressed; speculum with sparse punctures, shining (Fig. 11E); scutellum slightly convex, with carinae developed only at base (Fig. 11G); basal area of propodeum with protuberance; area superomedia of propodeum $1.42 \times$ longer than wide, costulae beyond middle of area superomedia (Fig. 11G); length of propodeal spiracles $3 \times$ its width; hind femur $3.33 \times$ its width; fore wings $0.65 \times$ length of body; areolet pentagonal and lower internal angle of discocubital cell is the right; T2 at apex, of equal length and breadth (Fig. $11 \mathrm{H})$; middle field of postpetiole densely punctured; gastrocoeli deep and thyridia wider than interval between them (Fig. 11F).

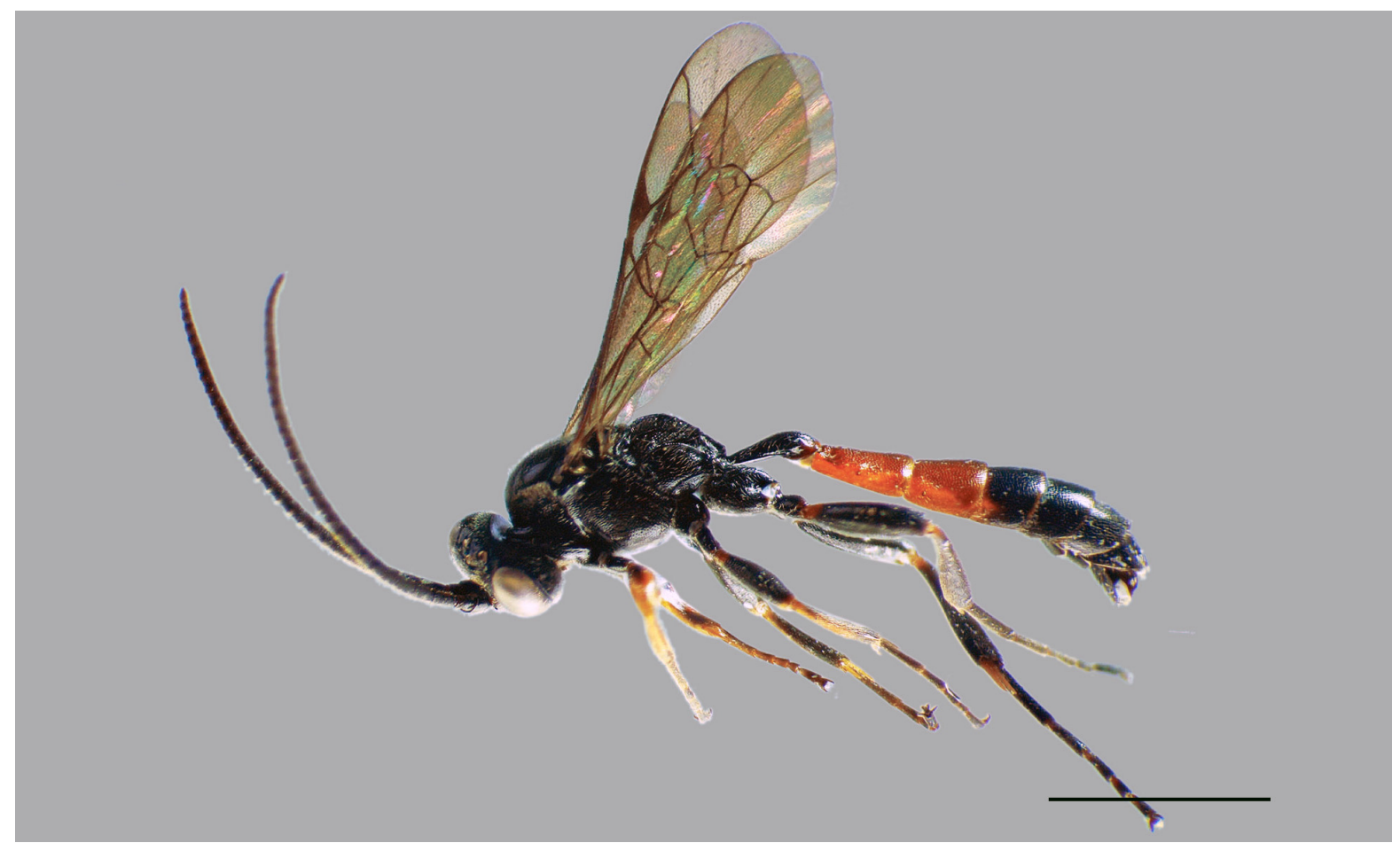

Figure 10. Lateral male habitus of Stenobarichneumon basalis (Perkins, 1960) (scale bar: 3 mm). 

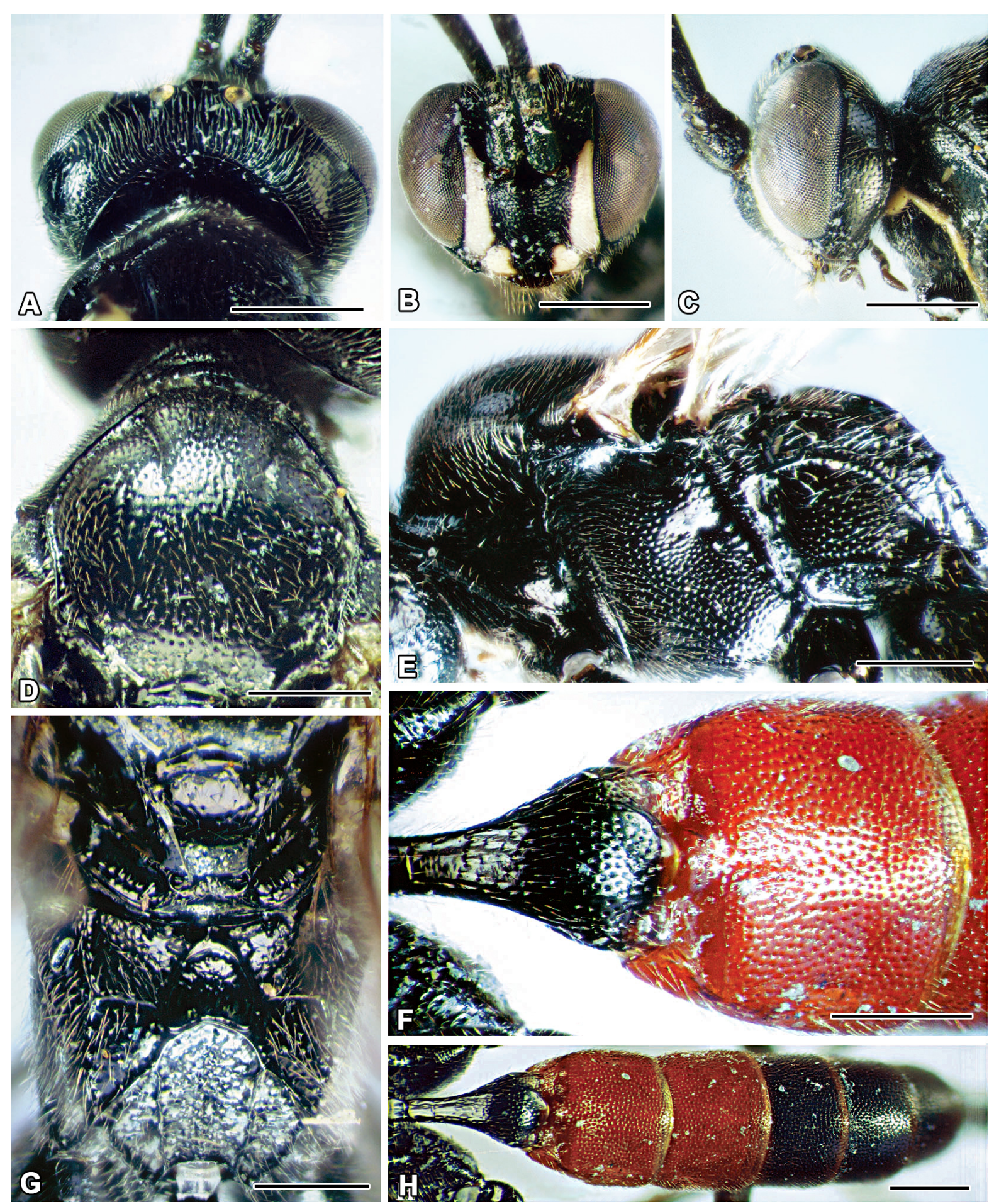

Figure 11. Stenobarichneumon basalis (Perkins, 1960), male; A. Head, dorsal view, B. Head, frontal view, C. Head, lateral view, D. Mesonotum, dorsal view, E. Mesosoma, lateral view, F. T1-T2, dorsal view, G. Scutellum and propodeum, dorsal view, H. Metasoma, dorsal view (scale bars: $A-B, D-F, H=0.5 \mathrm{~mm}, C, G=1 \mathrm{~mm}$ ).

Coloration. Head and thorax black; face and clypeus broadly ivory laterally; scutellum black; legs black (fore and mid legs with red pattern); T2-T3 red. 
General distribution. Western Palaearctic region (Yu et al., 2016) and Iran (new record).

Distribution in Iran. Alborz province (Current study).

Stenobarichneumon basiglyptus (Kriechbaumer, 1890)

Material examined. Iran, Guilan province: Ghazichak (36² $45^{\prime} 54^{\prime \prime}$ N, 50¹9'36" E, $1803 \mathrm{~m}$ a.s.1.), 05.VII.2010, 10; TMUC, leg.: M. Khayrandish.

General distribution. Western and Eastern Palaearctic region (Yu et al., 2016).

Distribution in Iran. Golestan, Khuzestan, Mazandaran, Yazd (Kolarov \& Ghahari, 2008) and Guilan (new provincial record) provinces.

Virgichneumon albilineatus (Gravenhorst, 1820) (Fig. 12; Figs 13A-H)

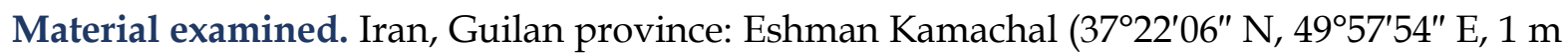

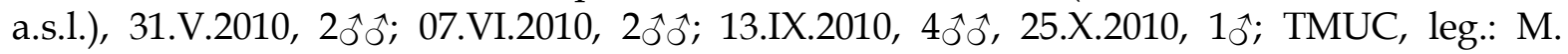
Khayrandish.

Diagnostic characters (male). Body length 13-16 mm (Fig. 12); vertex slightly roundly slanting down after the ocelli to occipital carina in lateral view (Fig. 13C); temple approximately equal to transverse diameter of eye at the middle, slightly roundly narrowed behind eyes in dorsal view (Fig. 13A); occipital carina not extending to posterior ocelli in dorsal view; middle field of face distinct, but slightly elevated, surface of face densely punctured; clypeus $1.9 \times$ wider than length, apical margin of clypeus straight, separated from face by slight impression; surface of clypeus with, sparse delicate not uniform punctures, shining (Fig. 13B); malar space $0.57 \times$ basal width of mandible; occipital carina meeting hypostomal carina far from base of mandibles; mandibles strong, slightly evenly narrowed behind base, upper tooth longer than lower; antennal cavities deeply impressed, reach borders of eyes and far not reach front ocellus level; margins of antennal socket slightly elevated above face surface (Fig. 13B); flagellum with 42 segments, basal segment from the side $2.1 \times$ longer than width at apex; narrow tyloides on segments 7-17; transverse furrow of pronotum shallow, not interrupted by keel (Fig. 13A); mesoscutum only just convex, $1.03 \times$ longer than wide; notauli in form of very slight impressions at base (Fig. 13D); upper part of mesopleura under subalarum with wrinkly-punctured, other part of mesopleura densely punctured (Fig. 13E); speculum smooth, shining; scutellum slightly convex, not carinated laterally, dorsal surface sparsely punctured (Fig. 13G); area superomedia $1.66 \times$ wider than long, costulae at middle (Fig. 13G); propodeal spiracles $3.2 \times$ longer than width; front tarsus with segment 1 expanded apically, externally into a sharp tooth (Fig. 13F); T2 at apex $1.1 \times$ wider than length $($ Fig. $13 \mathrm{H})$; middle field of postpetiole slightly elevated, its surface punctured; gastrocoeli deeply impressed, approximately triangular, with distinct thyridia, interval wider than breadth of thyridia; surface of tergites of metasoma densely punctured, slightly shining (Fig. 13H).

Coloration. Body black; frontal orbit broadly ivory, the ivory mark extending at least to two-thirds the distance from the orbit to the posterior ocellus; face and clypeus broadly ivory laterally; pronotal collar (front margin of pronotum) ivory centrally; pronotal ridge, hind corner of pronotum, tegula and subalarum marked with ivory; scutellum in greater part ivory; hind femur black; tibia and usually tarsal segments of the legs marked with ivory; postpetiole marked with ivory apically. 


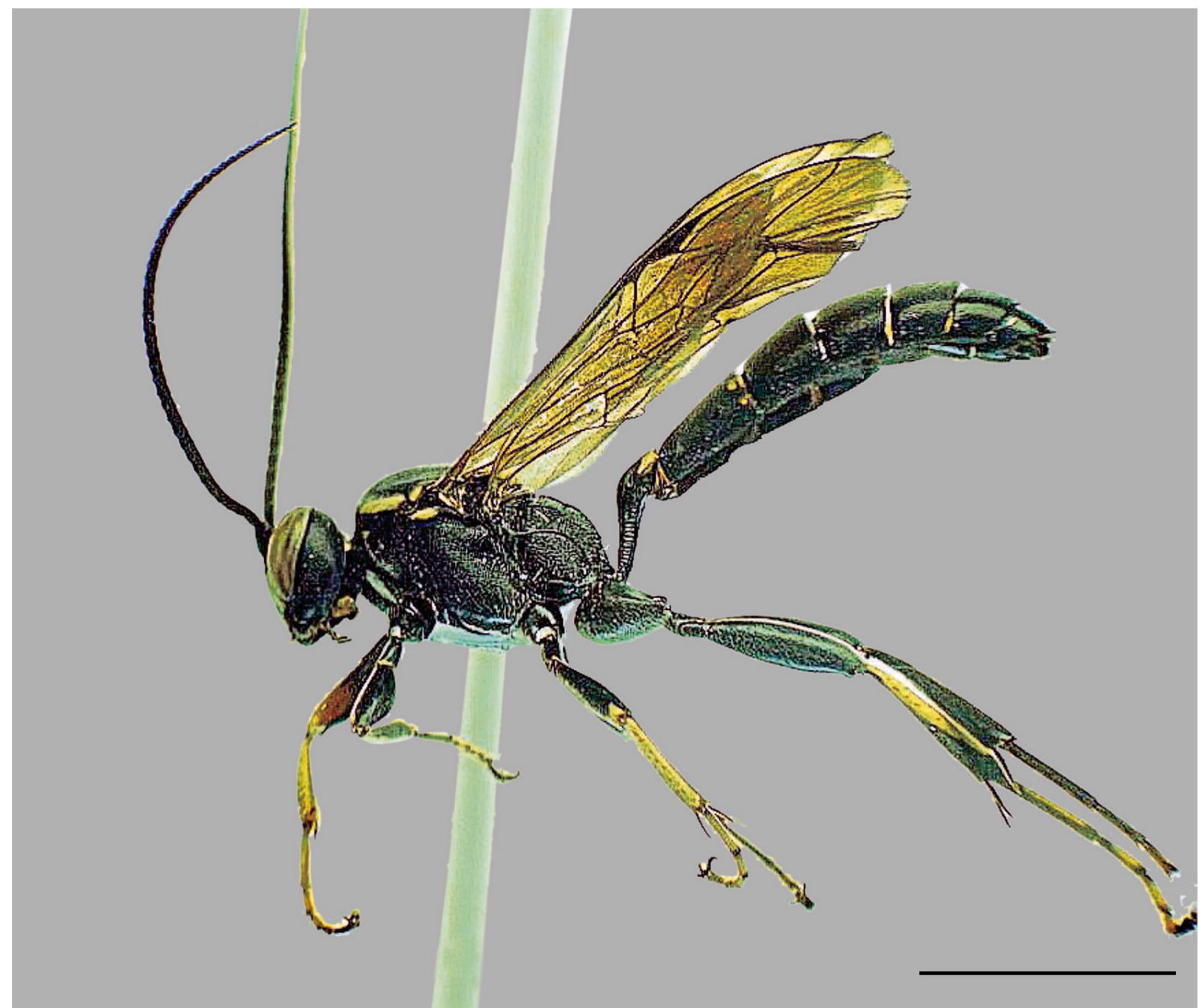

Figure 12. Lateral habitus of male in Virgichneumon albilineatus (Gravenhorst, 1820) (scale bar: $5 \mathrm{~mm})$.

General distribution. Western and Eastern Palaearctic and Oriental regions (Yu et al., 2016).

Distribution in Iran. Guilan (new provincial record) and Mazandaran (Hooshyar et al., 2019) provinces.

\section{Virgichneumon digrammus (Gravenhorst, 1820)}

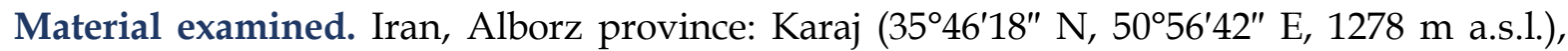

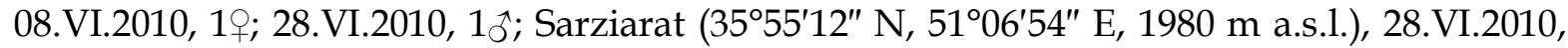

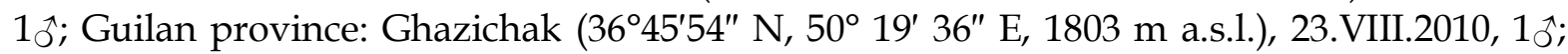

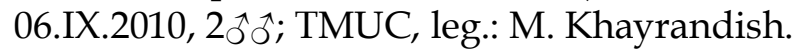

General distribution. Western and Eastern Palaearctic region (Yu et al., 2016).

Distribution in Iran. Alborz, Guilan (new provincial record); Golestan and Razavi Khorasan (Kolarov \& Ghahari, 2008) provinces. 

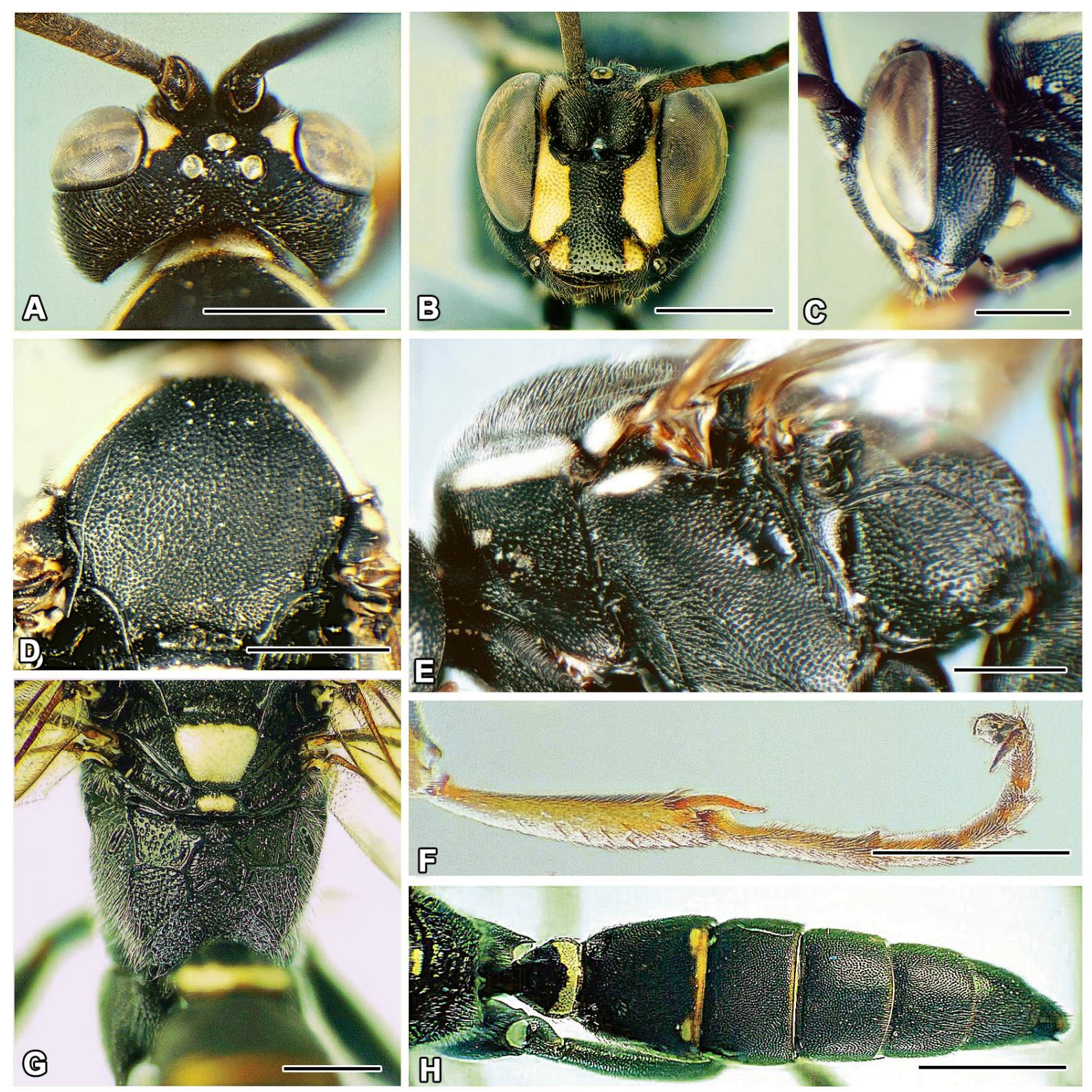

Figure 13. Virgichneumon albilineatus (Gravenhorst, 1820), male; A. Head, dorsal view, B. Head, frontal view, C. Head, lateral view, D. Mesonotum, dorsal view, E. Mesosoma, lateral view, F. Front tarsus, lateral view, G. Mesonotum and scutellum, dorsal view, H. Metasoma, dorsal view (scale bars: $A=1.5 \mathrm{~mm}, \mathrm{~B}-\mathrm{G}=1 \mathrm{~mm}, \mathrm{H}=2 \mathrm{~mm}$ ).

Virgichneumon dumeticola (Gravenhorst, 1829)

Material examined. Iran, Guilan province: Eshman Kamachal (37²2'06" N, 4957'54" E, 1 m

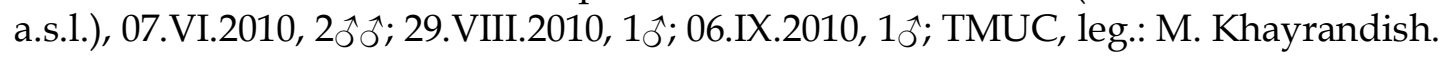

General distribution. Western and Eastern Palaearctic and Oriental regions ( $\mathrm{Yu}$ et al., 2016).

Distribution in Iran. Guilan (Riedel \& Aghadokht, 2017; current study) province. 


\section{Vulgichneumon deceptor (Scopoli, 1763)}

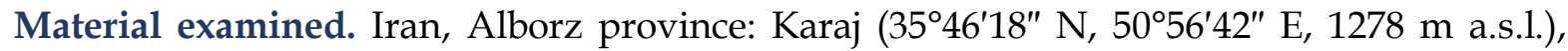

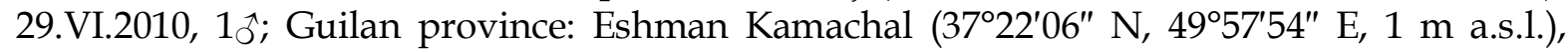

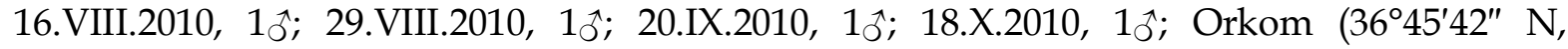

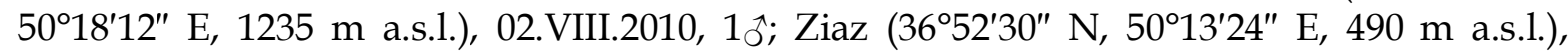

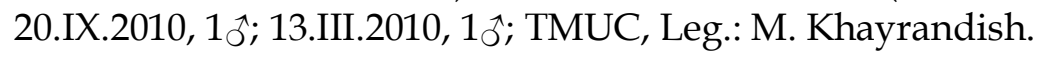

General distribution. Western and Eastern Palaearctic region (Yu et al., 2016).

Distribution in Iran. Alborz, Guilan (new provincial record), Golestan (Aghadokht et al., 2017) and Qazvin (Ghahari \& Schwarz, 2012) provinces.

\section{Discussion}

As a result of this study and review of the previously recorded taxa, 143 species of Ichneumonini are now reported for the Iranian fauna (Table 1). There were unreliable records of six species (e. g., Ichneumon fulvicornis Gravenhorst, 1829; Ichneumon haematofemur Heinrich, 1980; Ichneumon ignobilis Wesmael, 1855; Ichneumon phaeostigmus Wesmael, 1857; Ichneumon suspiciosus Wesmael, 1845; Limerodops subsericans (Gravenhorst, 1820) which are excluded from the current list of valid records, until the accession to and examination of the voucher specimens. Furthermore, these species have been published in invalid and predatory journals.

Considering the high species richness of the tribe Ichneumonini with more than 1300 known species in the Western Palaearctic (Yu et al., 2016), and the high number of recent new records and new species of the family Ichneumonidae from Iran (Riedel \& Aghadokht, 2017; Shirzadegan et al., 2018; Reidel et al., 2019; Zardouei Heydari et al., 2019, 2020a, 2020b, 2020c, 2020d; Falahatpisheh et al., 2021), future studies in intact and unexplored regions, will get a more complete picture of the tribe as well as ichneumonid fauna in Iran. This is also the case for other neighbouring countries of Iran. The number of species of the tribe Ichneumonini is recorded as 325 species in the former USSR and 103 species in Turkey, whereas only five species are recorded in Tajikistan, nine in Turkmenistan, six in Armenia, 10 in Afghanistan, 81 in Azerbaijan and one in Iraq (Yu et al., 2016).

Table 1. The updated list of the tribe Ichneumonini (Hymenoptera: Ichneumonidae, Ichneumoninae) of Iran.

\begin{tabular}{cccl}
\hline No & \multicolumn{1}{c}{ Species } & $\begin{array}{c}\text { Distribution in Iran } \\
\text { (provinces) }\end{array}$ & \multicolumn{1}{c}{ References } \\
\hline 1 & Amblyteles armatorius (Forster, 1771) & $\begin{array}{c}\text { Guilan, Isfahan, Yazd, } \\
\text { East Azarbaijan }\end{array}$ & $\begin{array}{l}\text { Kolarov \& Ghahari, } \\
\text { 2008; Masnadi \& } \\
\text { Jussila, 2008; current } \\
\text { study }\end{array}$ \\
$2 \begin{array}{c}\text { Anisopygus persicus Shirzadegan, Talebi \& } \\
\text { Riedel sp. nov. }\end{array}$ & Guilan & current study \\
$\begin{array}{c}\text { Barichneumon albicaudatus (Fonscolombe, } \\
\text { 1847) } \\
\text { Barichneumon bilunulatus (Gravenhorst, } \\
\text { 1829) }\end{array}$ & West Azarbaijan & $\begin{array}{l}\text { Kolarov \& Ghahari, } \\
\text { 2008 } \\
\text { Kolarov \& Ghahari, } \\
\text { 2008 }\end{array}$ \\
\hline
\end{tabular}


Table 1. Continued.

\begin{tabular}{|c|c|c|c|}
\hline No & Species & $\begin{array}{l}\text { Distribution in Iran } \\
\text { (provinces) }\end{array}$ & References \\
\hline 5 & $\begin{array}{l}\text { Barichneumon brevipunctatus Riedel, Ameri, } \\
\text { Talebi \& Ebrahimi, } 2019\end{array}$ & Khuzestan, Markazi & Riedel et al., 2019 \\
\hline 6 & Barichneumon chionomus (Wesmael, 1845) & $\begin{array}{l}\text { Razavi Khorasan, } \\
\text { Alborz, Guilan }\end{array}$ & $\begin{array}{l}\text { Ghahari \& Jussila, } \\
\text { 2014; current study }\end{array}$ \\
\hline 7 & Barichneumon derogator (Wesmael, 1845) ${ }^{* * *}$ & $\begin{array}{c}\text { Fars, Golestan, } \\
\text { Guilan, Kerman, } \\
\text { Tehran }\end{array}$ & $\begin{array}{l}\text { Hasanshahi et al., } \\
\text { 2014; Mohebban et } \\
\text { al., 2015; Aghadokht } \\
\text { et al., 2017; } \\
\text { Falahatpisheh et al., } \\
\text { 2021; current study }\end{array}$ \\
\hline 8 & Barichneumon gaullei (Berthoumieu, 1903) ${ }^{* * *}$ & $\begin{array}{l}\text { Kerman, Alborz, } \\
\text { Guilan }\end{array}$ & $\begin{array}{l}\text { Mohebban et al., } \\
\text { 2016; current study }\end{array}$ \\
\hline 9 & Barichneumon peregrinator (Linnaeus, 1758) & Ilam, Kermanshah & $\begin{array}{l}\text { Kolarov \& Ghahari, } \\
2008\end{array}$ \\
\hline 10 & Barichneumon plagiarius (Wesmael, 1848) & Qazvin, Mazandaran & $\begin{array}{l}\text { Ghahari \& Schwarz, } \\
\text { 2012; Hooshyar et al., } \\
2019\end{array}$ \\
\hline 11 & $\begin{array}{l}\text { Barichneumon quadriguttatus (Gravenhorst } \\
\text { 1829) }\end{array}$ & $\begin{array}{l}\text { Kordestan, Golestan, } \\
\text { Ardabil, East } \\
\text { Azarbaijan }\end{array}$ & $\begin{array}{l}\text { Kolarov \& Ghahari, } \\
\text { 2008; Ghahari \& } \\
\text { Jussila, 2010a, 2010b }\end{array}$ \\
\hline 12 & Barichneumon sexalbatus (Gravenhorst, 1820) & Golestan & $\begin{array}{l}\text { Riedel \& Aghadokht, } \\
\text { 2017; Aghadokht et } \\
\text { al., } 2017\end{array}$ \\
\hline 13 & Chasmias masanderanicus (Heinrich, 1929) & Mazandaran & Heinrich, 1929 \\
\hline 14 & Cratichneumon coruscator (Linnaeus, 1758) & $\begin{array}{l}\text { Golestan, } \\
\text { Mazandaran }\end{array}$ & $\begin{array}{l}\text { Heinrich, 1929; Kolarov } \\
\text { \& Ghahari, } 2008\end{array}$ \\
\hline 15 & Cratichneumon culex (Muller, 1776) & $\begin{array}{l}\text { Isfahan, Guilan, } \\
\text { Golestan, } \\
\text { Mazandaran, North } \\
\text { Khorasan, Semnan, } \\
\text { West Azarbaijan }\end{array}$ & $\begin{array}{l}\text { Kolarov \& } \text { Ghahari, } \\
\text { 2008; Ghahari \& } \\
\text { Jussila, } \\
\text { Aghadokht et al., 2011c; }\end{array}$ \\
\hline 16 & Cratichneumon flavifrons (Schrank, 1781) & Golestan & Aghadokht et al., 2017 \\
\hline 17 & Cratichneumon rufifrons (Gravenhorst, 1829) & $\begin{array}{l}\text { East Azarbaijan, } \\
\text { Razavi Khorasan }\end{array}$ & $\begin{array}{l}\text { Kolarov \& Ghahari, } \\
\text { 2008; Barahoei et al., } \\
2012\end{array}$ \\
\hline 18 & Cratichneumon semirufus (Gravenhorst, 1820) & Kerman & $\begin{array}{l}\text { Kolarov \& Ghahari, } \\
2008\end{array}$ \\
\hline 19 & $\begin{array}{l}\text { Cratichneumon sexarmillatus (Kriechbaumer, } \\
\text { 1891) }\end{array}$ & Mazandaran & $\begin{array}{l}\text { Kolarov \& Ghahari, } \\
2008\end{array}$ \\
\hline 20 & Cratichneumon stenocarus (Thomson, 1887) & Guilan & Heinrich, 1929 \\
\hline 21 & Cratichneumon versator (Thunberg, 1822) & Guilan & Heinrich, 1929 \\
\hline
\end{tabular}


Table 1. Continued.

\begin{tabular}{|c|c|c|c|}
\hline No & Species & $\begin{array}{l}\text { Distribution in Iran } \\
\text { (provinces) }\end{array}$ & References \\
\hline 22 & Crypteffigies lanius (Gravenhorst, 1829) & Golestan & $\begin{array}{l}\text { Riedel \& Aghadokht, } \\
\text { 2017; Aghadokht et } \\
\text { al., } 2017\end{array}$ \\
\hline 23 & Crytea sanguinator (Desvignes, 1856) & West Azarbaijan, & $\begin{array}{l}\text { Ghahari \& Jussila, } \\
\text { 2010b }\end{array}$ \\
\hline 24 & Ctenichneumon castigator (Fabricius, 1793) & $\begin{array}{l}\text { Guilan, Golestan, } \\
\text { Mazandaran, Razavi } \\
\text { Khorasan, Tehran }\end{array}$ & $\begin{array}{l}\text { Heinrich, 1929; } \\
\text { Kolarov \& Ghahari, } \\
\text { 2008; Masnadi \& } \\
\text { Jussila, 2008; Ghahari } \\
\text { \& Jussila, 2014; } \\
\text { current study }\end{array}$ \\
\hline 25 & Ctenichneumon devylderi Holmgren, 1871 & $\begin{array}{l}\text { Alborz, Ghom, } \\
\text { Kerman }\end{array}$ & $\begin{array}{l}\text { Masnadi \& Jussila, } \\
\text { 2008; Mohebban et al., } \\
\text { 2015; Falahatpisheh et } \\
\text { al., 2021; current } \\
\text { study }\end{array}$ \\
\hline 26 & Ctenichneumon divisorius Gravenhorst, 1820 & Guilan; Qazvin & $\begin{array}{l}\text { Kolarov \& Ghahari, } \\
\text { 2008; Ghahari \& } \\
\text { Schwarz, } 2012\end{array}$ \\
\hline 27 & Ctenichneumon edictorius Linnaeus, 1758 & Guilan, Golestan & Heinrich, 1929 \\
\hline 28 & Ctenichneumon funereus Geoffroy, 1785 & Razavi Khorasan & Ghahari \& Jussila, 2014 \\
\hline 29 & Ctenichneumon inspector (Wesmael, 1845) & $\begin{array}{l}\text { Alborz, Guilan, } \\
\text { Tehran }\end{array}$ & current study \\
\hline 30 & $\begin{array}{l}\text { Ctenichneumon melanocastaneus } \\
\text { (Gravenhorst, 1820) }\end{array}$ & Guilan; Golestan & $\begin{array}{l}\text { Heinrich, 1929; } \\
\text { Aghadokht et al., 2017 }\end{array}$ \\
\hline 31 & Ctenichneumon panzeri (Wesmael, 1845) & $\begin{array}{l}\text { Guilan, Golestan, } \\
\text { Sistsn and } \\
\text { Baluchestan, } \\
\text { Mazandaran, Razavi } \\
\text { Khorasan }\end{array}$ & $\begin{array}{l}\text { Heinrich, 1929; } \\
\text { Ghadiri et al., 2007; } \\
\text { Kolarov \& Ghahari, } \\
\text { 2008; Masnadi \& } \\
\text { Jussila, 2008; Ghahari } \\
\text { \& Jussila, 2014; } \\
\text { current study }\end{array}$ \\
\hline 32 & $\begin{array}{l}\text { Ctenichneumon repentinus (Gravenhorst, } \\
\text { 1820* }^{* * *}\end{array}$ & $\begin{array}{c}\text { Alborz, Guilan, } \\
\text { Tehran, East } \\
\text { Azarbaijan, West } \\
\text { Azarbaijan, }\end{array}$ & $\begin{array}{l}\text { Kolarov \& Ghahari, } \\
\text { 2008; current study }\end{array}$ \\
\hline 33 & Ctenichneumon tristator (Habermehl, 1920) & $\begin{array}{l}\text { Golestan, West } \\
\text { Azarbaijan }\end{array}$ & $\begin{array}{l}\text { Riedel \& Aghadokht, } \\
2017\end{array}$ \\
\hline 34 & Diphyus amatorius (Müller, 1776) & Guilan & Heinrich, 1929 \\
\hline 35 & Diphyus elbursicus (Heinrich, 1929) & Guilan & Heinrich, 1929 \\
\hline 36 & Diphyus longimanus (Wesmael, 1857) & $\begin{array}{l}\text { Golestan, West } \\
\text { Azarbaijan }\end{array}$ & $\begin{array}{l}\text { Riedel \& Aghadokht, } \\
2017\end{array}$ \\
\hline
\end{tabular}


Table 1. Continued.

\begin{tabular}{|c|c|c|c|}
\hline No & Species & $\begin{array}{l}\text { Distribution in Iran } \\
\text { (provinces) }\end{array}$ & References \\
\hline 37 & Diphyus luctatorius (Linnaeus, 1758) & North Khorasan & $\begin{array}{l}\text { Kolarov \& Ghahari, } \\
2008\end{array}$ \\
\hline 38 & Diphyus mercatorius (Fabricius, 1793) & $\begin{array}{c}\text { Ardabil, Guilan, } \\
\text { Qazvin }\end{array}$ & $\begin{array}{l}\text { Heinrich, 1929; } \\
\text { Masnadi \& Jussila. } \\
\text { 2008; Ghahari \& } \\
\text { Schwarz, } 2012\end{array}$ \\
\hline 39 & Diphyus montivagans (Berthoumieu, 1897) & $\begin{array}{c}\text { Golestan, West } \\
\text { Azarbaijan }\end{array}$ & $\begin{array}{l}\text { Riedel \& Aghadokht, } \\
2017\end{array}$ \\
\hline 40 & Diphyus ochromelas (Gmelin, 1790)*** & Ardabil, Guilan & $\begin{array}{l}\text { Kolarov \& Ghahari, } \\
\text { 2008; Masnadi \& } \\
\text { Jussila. 2008; current } \\
\text { study }\end{array}$ \\
\hline 41 & Diphyus palliatorius (Gravenhorst, 1829) & $\begin{array}{c}\text { Mazandaran, Razavi } \\
\text { Khorasan }\end{array}$ & $\begin{array}{l}\text { Kolarov \& Ghahari, } \\
\text { 2008; Ghahari \& } \\
\text { Jussila, } 2014\end{array}$ \\
\hline 42 & Diphyus pedatus (Berthoumieu, 1895) & Guilan & Heinrich, 1929 \\
\hline 43 & Diphyus ponticus Heinrich, 1978 & Not defined & Heinrich, 1978 \\
\hline 44 & Diphyus pseudocastigator (Heinrich, 1929) & Guilan & Heinrich, 1929 \\
\hline 45 & Diphyus quadripunctorius (Müller, 1776) & $\begin{array}{l}\text { Mazandaran, } \\
\text { Semnan }\end{array}$ & $\begin{array}{l}\text { Kolarov \& Ghahari, } \\
2008\end{array}$ \\
\hline 46 & Diphyus raptorius (Linneaus, 1758 ) & Guilan & $\begin{array}{l}\text { Kolarov \& Ghahari, } \\
2008\end{array}$ \\
\hline 47 & Diphyus septemguttatus (Gravenhorst, 1829) & $\begin{array}{c}\text { Guilan, Golestan, } \\
\text { Mazandaran }\end{array}$ & $\begin{array}{l}\text { Heinrich, 1929; } \\
\text { Kolarov \& Ghahari, } \\
2008\end{array}$ \\
\hline 48 & Eupalamus lacteator (Gravenhorst, 1829) & $\begin{array}{c}\text { Golestan, West } \\
\text { Azarbaijan }\end{array}$ & $\begin{array}{l}\text { Riedel \& Aghadokht, } \\
2017\end{array}$ \\
\hline 49 & Eutanyacra glaucatoria (Fabricius, 1793) & $\begin{array}{l}\text { Golestan, Qazvin; } \\
\text { Razavi Khorasan, }\end{array}$ & $\begin{array}{l}\text { Kolarov \& Ghahari, } \\
\text { 2008; Masnadi \& } \\
\text { Jussila, 2008; Ghahari } \\
\text { \& Schwarz, } 2012\end{array}$ \\
\hline 50 & Eutanyacra sanguinolenta (Heinrich, 1929) & Golestan & Heinrich, 1929 \\
\hline 51 & Eutanyacra picta (Schrank, 1776) & $\begin{array}{c}\text { Guilan, Fars, Isfahan, } \\
\text { Kerman, Golestan, } \\
\text { Kerman }\end{array}$ & $\begin{array}{l}\text { Heinrich, 1929; } \\
\text { Kolarov \& Ghahari, } \\
\text { 2008; Masnadi \& } \\
\text { Jussila, } \\
\text { Mohebban et al., 2015; }\end{array}$ \\
\hline 52 & Eutanyacra ruficornis (Berthoumieu, 1894) & Alborz & current study \\
\hline 53 & Exephanes ischioxanthus Gravenhorst, 1829 & Lorestan & $\begin{array}{l}\text { Ghahari \& Gadallah, } \\
2015\end{array}$ \\
\hline
\end{tabular}


Table 1. Continued.

\begin{tabular}{|c|c|c|c|}
\hline No & Species & $\begin{array}{l}\text { Distribution in Iran } \\
\text { (provinces) }\end{array}$ & References \\
\hline 54 & Exephanes occupator (Gravenhorst, 1829) & $\begin{array}{l}\text { Guilan, East } \\
\text { Azarbaijan }\end{array}$ & $\begin{array}{l}\text { Heinrich, 1929; Kolarov } \\
\text { \& Ghahari, } 2008\end{array}$ \\
\hline 55 & Exephanes tauricus Hinz, 2000 & Ilam & Darvishnia et al., 2018 \\
\hline 56 & Fileanta flavolaeta (Berthoumieu, 1892) & Ghom & $\begin{array}{l}\text { Masnadi \& Jussila, } \\
2008\end{array}$ \\
\hline 57 & Fileanta radoszkowskii (Berthoumieu, 1892) & $\begin{array}{l}\text { Golestan, West } \\
\text { Azarbaijan }\end{array}$ & $\begin{array}{l}\text { Riedel \& Aghadokht, } \\
2017\end{array}$ \\
\hline 58 & Homotherus locutor (Thunberg 1822) & Razavi Khorasan & Ghahari \& Jussila, 2014 \\
\hline 59 & Hoplismenus bidentatus (Gmelin, 1790) & Qazvin & $\begin{array}{l}\text { Ghahari \& Schwarz, } \\
2012\end{array}$ \\
\hline 60 & Hoplismenus bispinatorius (Thunberg, 1824) & $\begin{array}{c}\text { Guilan, Mazandaran, } \\
\text { Zanjan }\end{array}$ & $\begin{array}{l}\text { Kolarov \& Ghahari, } \\
2008\end{array}$ \\
\hline 61 & Hoplismenus lamprolabus Wesmael, 1857 & Tehran, Lorestan & $\begin{array}{l}\text { Masnadi \& Jussila, } \\
2008\end{array}$ \\
\hline 62 & Ichneumon albicollis Wesmael, 1857 & West Azarbaijan & $\begin{array}{l}\text { Ghahari \& Jussila, } \\
2010 b\end{array}$ \\
\hline 63 & Ichneumon balteatus Wesmael, 1845 & $\begin{array}{c}\text { Fars, Bushehr; } \\
\text { Razavi Khorasan }\end{array}$ & $\begin{array}{l}\text { Kolarov \& Ghahari, } \\
\text { 2008; Ghahari \& } \\
\text { Jussila, } 2014\end{array}$ \\
\hline 64 & Ichneumon bucculentus Wesmael, 1845 & $\begin{array}{l}\text { Tehran, Semnan, } \\
\text { Mazandaran, } \\
\text { Golestan; Tehran }\end{array}$ & $\begin{array}{l}\text { Kolarov \& Ghahari, } \\
2008\end{array}$ \\
\hline 65 & Ichneumon caedator Gravenhorst, 1829 & North Khorasan & $\begin{array}{l}\text { Kolarov \& Ghahari, } \\
2008\end{array}$ \\
\hline 66 & Ichneumon caloscelis Wesmael, 1845 & Guilan, Yazd, Tehran & $\begin{array}{l}\text { Kolarov \& Ghahari, } \\
\text { 2008; Masnadi \& } \\
\text { Jussila, 2008; Zarepour } \\
\text { et al., 2008, } 2009\end{array}$ \\
\hline 67 & Ichneumon caucasicus Meyer 1926 & $\begin{array}{l}\text { Guilan, Golestan, } \\
\text { Mazandaran }\end{array}$ & Heinrich, 1929 \\
\hline 68 & Ichneumon cerinthius Gravenhorst, 1820 & Guilan & Heinrich, 1929 \\
\hline 69 & Ichneumon cessator Müller, 1776 & $\begin{array}{l}\text { Guilan, Golestan, } \\
\text { Mazandaran }\end{array}$ & $\begin{array}{l}\text { Heinrich, 1929; Kolarov } \\
\text { \& Ghahari, } 2008\end{array}$ \\
\hline 70 & Ichneumon confusor Gravenhorst, 1820 & Qazvin & $\begin{array}{l}\text { Ghahari \& Schwarz, } \\
2012\end{array}$ \\
\hline 71 & Ichneumon curtulus Kriechbaumer, 1882 & Lorestan & $\begin{array}{l}\text { Heinrich, 1929; Ghahari } \\
\text { \& Gadalla, } 2015\end{array}$ \\
\hline 72 & Ichneumon erythromerus Wesmael, 1857 & Southern Khorasan & $\begin{array}{l}\text { Ghahari \& Jussila, } \\
2014\end{array}$ \\
\hline 73 & Ichneumon eumerus Wesmael, 1857 & Guilan & Heinrich, 1929 \\
\hline
\end{tabular}


Table 1. Continued.

\begin{tabular}{|c|c|c|c|}
\hline No & Species & $\begin{array}{l}\text { Distribution in Iran } \\
\text { (provinces) }\end{array}$ & References \\
\hline 74 & Ichneumon exilicornis Wesmael, 1857 & Qazvin & $\begin{array}{l}\text { Ghahari \& Schwarz, } \\
2012\end{array}$ \\
\hline 75 & Ichneumon gracilentus Wesmael, 1845 & Kordestan & $\begin{array}{l}\text { Kolarov \& Ghahari, } \\
2008\end{array}$ \\
\hline 76 & Ichneumon gracilicornis Gravenhorst, 1829 & Qazvin & $\begin{array}{l}\text { Ghahari \& Schwarz, } \\
2012\end{array}$ \\
\hline 77 & Ichneumon gratus Wesmael, 1855 & Lorestan & $\begin{array}{l}\text { Ghahari \& Gadalla, } \\
2015\end{array}$ \\
\hline 78 & $\begin{array}{l}\text { Ichneumon haemorrhoicus crassigena } \\
\text { Kriechbaumer, } 1887\end{array}$ & $\begin{array}{l}\text { Guilan, Khuzestan, } \\
\text { West Azarbaijan }\end{array}$ & $\begin{array}{l}\text { Heinrich, 1929; } \\
\text { Kolarov \& Ghahari, } \\
\text { 2008; Ghahari \& } \\
\text { Jussila, 2010b }\end{array}$ \\
\hline 79 & Ichneumon inops Holmgren, 1880 & Alborz & $\begin{array}{l}\text { Falahatpisheh et al., } \\
2021\end{array}$ \\
\hline 80 & Ichneumon insidiosus Wesmael, 1845 & $\begin{array}{l}\text { Kermanshah, } \\
\text { Khuzestan }\end{array}$ & $\begin{array}{l}\text { Kolarov \& Ghahari, } \\
2008\end{array}$ \\
\hline 81 & Ichneumon iranicus (Heinrich, 1929) & Golestan & Heinrich, 1929 \\
\hline 82 & Ichneumon languidus Wesmael, 1845 & $\begin{array}{l}\text { Guilan; Razavi } \\
\text { Khorasan }\end{array}$ & $\begin{array}{l}\text { Heinrich, 1929; } \\
\text { Ghahari \& Jussila, } 2014\end{array}$ \\
\hline 83 & Ichneumon lautatorius Desvignes, 1856 & $\begin{array}{l}\text { Golestan, West } \\
\text { Azarbaijan }\end{array}$ & $\begin{array}{l}\text { Riedel \& Aghadokht, } \\
2017\end{array}$ \\
\hline 84 & Ichneumon ligatorius Thunberg, 1824 & Razavi Khorasan & $\begin{array}{l}\text { Kolarov \& Ghahari, } \\
2008\end{array}$ \\
\hline 85 & Ichneumon melanosomus Wesmael, 1855 & $\begin{array}{l}\text { Alborz, West } \\
\text { Azarbaijan }\end{array}$ & $\begin{array}{l}\text { Kolarov \& Ghahari, } \\
\text { 2008; Barahoei et al., } \\
\text { 2012; Falahatpisheh } \\
\text { et al., } 2021\end{array}$ \\
\hline 86 & Ichneumon minutorius Desvignes, 1856 & Razavi Khorasan & $\begin{array}{l}\text { Kolarov \& Ghahari, } \\
\text { 2008; Ghahari \& } \\
\text { Jussila, } 2014\end{array}$ \\
\hline 87 & Ichneumon molitorius Cuvier, 1833 & $\begin{array}{l}\text { Golestan; Guilan, } \\
\text { Hamadan, Ilam }\end{array}$ & $\begin{array}{l}\text { Heinrich, 1929; Kolarov } \\
\text { \& Ghahari, 2008; } \\
\text { Aghadokht et al., } 2017\end{array}$ \\
\hline 88 & Ichneumon novemalbatus Kriechbaumer, 1875 & Not defined & Heinrich, 1929 \\
\hline 89 & Ichneumon persicus Heinrich, 1929 & Guilan & Heinrich, 1929 \\
\hline 90 & Ichneumon proletarius Wesmael, $1848^{* * *}$ & $\begin{array}{c}\text { Guilan, Golestan, } \\
\text { Sistan and } \\
\text { Baluchestan, Qazvin, } \\
\text { Tehran }\end{array}$ & $\begin{array}{l}\text { Heinrich, 1929; } \\
\text { Kolarov \& Ghahari, } \\
\text { 2008; Masnadi \& } \\
\text { Jussila, 2008; Ghahari } \\
\text { \& Schwarz, 2012; } \\
\text { current study }\end{array}$ \\
\hline
\end{tabular}


Table 1. Continued.

\begin{tabular}{|c|c|c|c|}
\hline No & Species & $\begin{array}{l}\text { Distribution in Iran } \\
\text { (provinces) }\end{array}$ & References \\
\hline 91 & $\begin{array}{l}\text { Ichneumon quadrialbatus (Gravenhorst, } \\
\text { 1820)** }\end{array}$ & Guilan & current study \\
\hline 92 & $\begin{array}{l}\text { Ichneumon ruficinctus (Townes, Momoi and } \\
\text { Townes, 1965) }\end{array}$ & Guilan & Heinrich, 1929 \\
\hline 93 & Ichneumon sarcitorius Linnaeus, 1758 & $\begin{array}{l}\text { East Azarbaijan; } \\
\text { Fars, Golestan, } \\
\text { Semnan, } \\
\text { Mazandaran }\end{array}$ & $\begin{array}{l}\text { Mojeni \& Sedivy, 2001; } \\
\text { Kolarov \& Ghahari, } \\
\text { 2008; Masnadi \& } \\
\text { Jussila, 2008; Sarafi et } \\
\text { al., 2015; Hooshyar et } \\
\text { al., 2019; Aghadokht et } \\
\text { al., 2017 }\end{array}$ \\
\hline 94 & Ichneumon sarcitorius caucasicus Meyer, 1926 & $\begin{array}{l}\text { Alborz, Kerman, } \\
\text { North Khorasan }\end{array}$ & $\begin{array}{l}\text { Ghahari \& Jussila } \\
\text { 2014; Falahatpisheh } \\
\text { et al., } 2021\end{array}$ \\
\hline 95 & $\begin{array}{l}\text { Ichneumon sarcitorius sarcitorius Linnaeus, } \\
\quad 1758\end{array}$ & $\begin{array}{c}\text { Alborz, } \\
\text { Gilan,Kerman, } \\
\text { Mazandaran, North } \\
\text { Khorasan, Razavi } \\
\text { Khorasan }\end{array}$ & $\begin{array}{l}\text { Ghahari \& Jussila, } \\
\text { 2014; Hooshyar et al., } \\
\text { 2019; Falahatpisheh et } \\
\text { al., } 2021\end{array}$ \\
\hline 96 & $\begin{array}{l}\text { Ichneumon sarcitorius turkestanicus (Heinrich, } \\
\text { 1929) ** }\end{array}$ & Alborz Guilan, Tehran & current study \\
\hline 97 & Ichneumon sexcinctus Gravenhorst, 1829 & Guilan, Lorestan & $\begin{array}{l}\text { Heinrich, 1929; Ghahari } \\
\text { \& Gadalla, } 2015\end{array}$ \\
\hline 98 & Ichneumon stramentarius Gravenhorst, 1820 & Qazvin & $\begin{array}{l}\text { Ghahari \& Schwarz, } \\
2012\end{array}$ \\
\hline 99 & Ichneumon tuberculipes Wesmael, 1848 & $\begin{array}{c}\text { Chaharmahal-o- } \\
\text { Bakhtiari, Isfahan, } \\
\text { Fars, Khuzestan, } \\
\text { Qazvin }\end{array}$ & $\begin{array}{l}\text { Kolarov \& Ghahari, } \\
\text { 2008; Ghahari \& } \\
\text { Schwarz, } 2012\end{array}$ \\
\hline 100 & Ichneumon vafer meridionalis Heinrich, 1929 & $\begin{array}{c}\text { Guilan, Mazandaran, } \\
\text { Golestan, Tehran, } \\
\text { West Azarbaijan, } \\
\text { East Azarbaijan, } \\
\text { Razavi Khorasan }\end{array}$ & $\begin{array}{l}\text { Heinrich, 1929; } \\
\text { Kolarov \& Ghahari, } \\
\text { 2008; Riedel et al, } \\
\text { 2010; Ghahari \& } \\
\text { Jussila, 2011b; Ghahari } \\
\text { \& Jussila, } 2014\end{array}$ \\
\hline 101 & Ichneumon xanthorius Forster, 1771 & Ilam, Mazandaran & $\begin{array}{l}\text { Kolarov \& Ghahari, } \\
\text { 2008; Masnadi \& } \\
\text { Jussila, } 2008\end{array}$ \\
\hline 102 & Melanichneumon glaucatoriops Heinrich, 1972 & North Khorasan & $\begin{array}{l}\text { Kolarov \& Ghahari, } \\
2008\end{array}$ \\
\hline 103 & $\begin{array}{l}\text { Melanichneumon leucocheilus (Wesmael, } \\
\text { 1845) }\end{array}$ & Golestan & $\begin{array}{l}\text { Riedel \& Aghadokht, } \\
\text { 2017; Aghadokht et } \\
\text { al., 2017 }\end{array}$ \\
\hline
\end{tabular}


Table 1. Continued.

\begin{tabular}{|c|c|c|c|}
\hline No & Species & $\begin{array}{l}\text { Distribution in Iran } \\
\text { (provinces) }\end{array}$ & References \\
\hline 104 & Obtusodonta carnifex (Kriechbaumer, 1882) & Guilan & Heinrich, 1929 \\
\hline 105 & Obtusodonta equitatoria (Panzer, 1786) & $\begin{array}{l}\text { Ardabil, Golestan, } \\
\text { Isfahan, Qazvin }\end{array}$ & $\begin{array}{l}\text { Masnadi \& Jussila, } \\
\text { 2008; Ghahari \& } \\
\text { Schwarz, 2012; } \\
\text { Aghadokht et al., } \\
2017\end{array}$ \\
\hline 106 & Obtusodonta erythrocephalus (Meyer, 1927) & Fars & $\begin{array}{l}\text { Masnadi \& Jussila, } \\
2008\end{array}$ \\
\hline 107 & Platylabops cornicula (Wesmael, 1855) & Semnan & $\begin{array}{l}\text { Kolarov \& Ghahari, } \\
2008\end{array}$ \\
\hline 108 & Platylabops humilis Wesmael, 1857 & North Khorasan & $\begin{array}{l}\text { Ghahari \& Jussila, } \\
2014\end{array}$ \\
\hline 109 & Platylabops mimus (Berthoumieu, 1899) & Golestan & $\begin{array}{l}\text { Riedel \& Aghadokht, } \\
\text { 2017; Aghadokht et } \\
\text { al., } 2017\end{array}$ \\
\hline 110 & Probolus concinnus Wesmael, 1853 & $\begin{array}{l}\text { Alborz, East } \\
\text { Azarbaijan }\end{array}$ & $\begin{array}{l}\text { Kolarov \& Ghahari, } \\
\text { 2008; Barahoei et al., } \\
\text { 2012; Falahatpisheh } \\
\text { et al., } 2021\end{array}$ \\
\hline 111 & Probolus crassulus Horstmann, $2000^{* * *}$ & Guilan, Lorestan & $\begin{array}{l}\text { Ghahari \& Gadalla, } \\
\text { 2015; current study }\end{array}$ \\
\hline 112 & Probolus culpatorius (Linnaeus, 1758)*** & $\begin{array}{l}\text { Alborz, Golestan, } \\
\text { Guilan }\end{array}$ & $\begin{array}{l}\text { Masnadi \& Jussila, } \\
\text { 2008; current study }\end{array}$ \\
\hline 113 & $\begin{array}{l}\text { Pseudoamblyteles homocerus (Wesmael, } \\
\text { 1854)*** }\end{array}$ & $\begin{array}{c}\text { Alborz, Razavi } \\
\text { Khorasan, Sistan and } \\
\text { Baluchestan }\end{array}$ & $\begin{array}{l}\text { Hedwig, 1957; } \\
\text { Barahoei et al., 2014b; } \\
\text { current study }\end{array}$ \\
\hline 114 & $\begin{array}{l}\text { Pseudoplatylabus uniguttatus (Gravenhorst, } \\
\text { 1829) }\end{array}$ & $\begin{array}{l}\text { Golestan, West } \\
\text { Azarbaijan }\end{array}$ & $\begin{array}{l}\text { Riedel \& Aghadokht, } \\
2017\end{array}$ \\
\hline 115 & $\begin{array}{l}\text { Pseudoplatylabus violentus (Gravenhorst, } \\
\text { 1829) }\end{array}$ & Qazvin & $\begin{array}{l}\text { Ghahari \& Schwarz, } \\
2012\end{array}$ \\
\hline 116 & Rictichneumon lombardi (Berthoumieu, 1897) & $\begin{array}{l}\text { Chaharmahal-o- } \\
\text { Bakhtiari, Qazvin }\end{array}$ & $\begin{array}{l}\text { Ghahari \& Jussila, } \\
\text { 2016; Ghahari \& } \\
\text { Schwarz, } 2012\end{array}$ \\
\hline 117 & Rictichneumon persicus Riedel, 2020 & Lorestan & Riedel, 2020 \\
\hline 118 & Spilichneumon occisorius (Fabricius, 1793) & $\begin{array}{l}\text { Southern Khorasan, } \\
\text { Razavi Khorasan }\end{array}$ & $\begin{array}{l}\text { Kolarov \& Ghahari, } \\
\text { 2008; Ghahari \& } \\
\text { Jussila, } 2014\end{array}$ \\
\hline 119 & $\begin{array}{l}\text { Spilichneumon tennecabunensis (Heinrich, } \\
\text { 1929) }\end{array}$ & Guilan & Heinrich, 1929 \\
\hline 120 & $\begin{array}{l}\text { Spilothyrateles illuminatorius (Gravenhorst, } \\
\text { 1820**** }\end{array}$ & $\begin{array}{l}\text { Alborz, } \\
\text { Mazandaran, } \\
\text { Guilan,Tehran }\end{array}$ & $\begin{array}{l}\text { Kolarov \& Ghahari, } \\
\text { 2008; current study }\end{array}$ \\
\hline
\end{tabular}


Table 1. Continued.

\begin{tabular}{|c|c|c|c|}
\hline No & Species & $\begin{array}{l}\text { Distribution in Iran } \\
\text { (provinces) }\end{array}$ & References \\
\hline 121 & $\begin{array}{l}\text { Spilothyrateles nuptatorius (Fabricius, } \\
\text { 1793)*** }\end{array}$ & $\begin{array}{c}\text { Alborz, Golestan, } \\
\text { Khuzestan, Markazi, } \\
\text { Qazin, Razavi } \\
\text { Khorasan }\end{array}$ & $\begin{array}{l}\text { Heinrich, 1929; Ghahari } \\
\& \quad \text { Schwarz, 2012; } \\
\text { Barahoei et al., 2014a, } \\
\text { 2015; Riedel et al., } \\
\text { 2019; Aghadokht et } \\
\text { al., 2017; current study }\end{array}$ \\
\hline 122 & Spilothyrateles punctus (Gravenhorst, 1829) & Guilan, Golestan & $\begin{array}{l}\text { Heinrich, 1929; Kolarov } \\
\& \text { Ghahari, } 2008\end{array}$ \\
\hline 123 & Stenichneumon culpator (Schrank, 1802) & $\begin{array}{l}\text { Golestan, Sistan and } \\
\text { Baluchestan, } \\
\text { Lorestan }\end{array}$ & $\begin{array}{l}\text { Heinrich, 1929; Kolarov } \\
\text { \& Ghahari, 2008; } \\
\text { Ghahari \& Gadalla, } \\
\text { 2015; Aghadokht et } \\
\text { al., 2017 }\end{array}$ \\
\hline 124 & Stenobarichneumon basalis (Perkins, 1960) ** & Alborz & current study \\
\hline 125 & $\begin{array}{l}\text { Stenobarichneumon basiglyptus } \\
(\text { Kriechbaumer, } 1890)^{* * *}\end{array}$ & $\begin{array}{l}\text { Golestan, Guilan, } \\
\text { Khuzestan, } \\
\text { Mazandaran, Yazd }\end{array}$ & $\begin{array}{l}\text { Kolarov \& Ghahari, } \\
\text { 2008; current study }\end{array}$ \\
\hline 126 & Stenobarichneumon citator (Thunberg, 1822) & $\begin{array}{l}\text { Ardabil, Golestan, } \\
\text { Khuzestan, } \\
\text { Mazandaran, Yazd }\end{array}$ & $\begin{array}{l}\text { Kolarov \& } \text { Ghahari, } \\
\text { 2008; Ghahari \& } \\
\text { Jussila, } \quad 2011 \text {; } \\
\text { Hooshyar et al., } 2019\end{array}$ \\
\hline 127 & Thyrateles camelinus (Wesmael, 1845) & Guilan & Heinrich, 1929 \\
\hline 128 & Triptognathus atripes (Gravenhorst, 1820) & Guilan & Heinrich, 1929 \\
\hline 129 & Triptognathus bolivari (Berthoumieu, 1894) & Guilan, Ardabil & $\begin{array}{l}\text { Heinrich, 1929; Masnadi } \\
\text { \& Jussila, } 2008\end{array}$ \\
\hline 130 & Triptognathus fumigator (Gravenhorst, 1820) & Not defined & Selfa, 1996 \\
\hline 131 & Triptognathus rubrocinctus (Lucas, 1849) & Guilan & Heinrich, 1929 \\
\hline 132 & Triptognathus unifasciatus (Spinola 1843) & $\begin{array}{l}\text { Guilan, Tehran, } \\
\text { Qazvim }\end{array}$ & $\begin{array}{l}\text { Heinrich, 1929; Masnadi } \\
\text { \& Jussila, } 2008\end{array}$ \\
\hline 133 & $\begin{array}{l}\text { Virgichneumon albilineatus (Gravenhorst, } \\
\text { 1820) *** }\end{array}$ & $\begin{array}{l}\text { Golestan, Guilan, } \\
\text { Mazandaran }\end{array}$ & $\begin{array}{l}\text { Hooshyar et al., 2019; } \\
\text { Aghadokht et al., } \\
\text { 2017; current study }\end{array}$ \\
\hline 134 & $\begin{array}{l}\text { Virgichneumon albosignatus (Gravenhorst, } \\
\text { 1829) }\end{array}$ & $\begin{array}{c}\text { Golestan, West } \\
\text { Azarbaijan, Razavi } \\
\text { Khorasan }\end{array}$ & $\begin{array}{lr}\text { Ghahari \& Jussila, } & \text { 2011a; Ghahari \& } \\
\text { Schwarz, } & \text { 2011; } \\
\text { Aghadokht et al., } 2017\end{array}$ \\
\hline 135 & Virgichneumon callicerus (Gravenhorst, 1820) & $\begin{array}{c}\text { Ardabil, East } \\
\text { Azarbaijan, Fars, } \\
\text { Khuzestan, Qazvin }\end{array}$ & $\begin{array}{l}\text { Kolarov \& Ghahari, } \\
\text { 2008; Masnadi \& } \\
\text { Jussila, 2008; Ghahari } \\
\text { \& Schwarz, 2012; } \\
\text { Safari et al., 2015; } \\
\text { Ghahari \& Jussila, 2016 }\end{array}$ \\
\hline
\end{tabular}


Table 1. Continued.

\begin{tabular}{|c|c|c|c|}
\hline No & Species & $\begin{array}{l}\text { Distribution in Iran } \\
\text { (provinces) }\end{array}$ & References \\
\hline 136 & $\begin{array}{l}\text { Virgichneumon digrammus (Gravenhorst, } \\
1820)^{* * *}\end{array}$ & $\begin{array}{c}\text { Alborz, Golestan, } \\
\text { Guilan, Razavi } \\
\text { Khorasan }\end{array}$ & $\begin{array}{l}\text { Kolarov \& Ghahari, } \\
\text { 2008; current study }\end{array}$ \\
\hline 137 & $\begin{array}{l}\text { Virgichneumon dumeticola (Gravenhorst, } \\
\text { 1829)*** }\end{array}$ & $\begin{array}{l}\text { Golestan, Guilan, } \\
\text { West Azarbaijan }\end{array}$ & $\begin{array}{l}\text { Riedel \& Aghadokht, } \\
\text { 2017; current study }\end{array}$ \\
\hline 138 & Virgichneumon maculicauda (Perkins, 1953) & $\begin{array}{l}\text { Mazandaran, } \\
\text { Tehran, Semnan, } \\
\text { Razavi Khorasan }\end{array}$ & $\begin{array}{l}\text { Kolarov \& Ghahari, } \\
\text { 2008; Ghahari \& } \\
\text { Jussila, } 2014\end{array}$ \\
\hline 139 & $\begin{array}{l}\text { Virgichneumon monostagon (Gravenhorst, } \\
\text { 1820) }\end{array}$ & Mazandaran & $\begin{array}{l}\text { Ghahari \& Jussila, } \\
\text { 2010b }\end{array}$ \\
\hline 140 & Vulgichneumon bimaculatus (Schrank, 1776) & $\begin{array}{l}\text { Guilan, Golestan, } \\
\text { Mazandaran }\end{array}$ & $\begin{array}{l}\text { Heinrich, 1929; } \\
\text { Kolarov \& Ghahari, } \\
2008\end{array}$ \\
\hline 141 & Vulgichneumon deceptor (Scopoli 1763) ${ }^{* * *}$ & $\begin{array}{l}\text { Alborz, Golestan, } \\
\text { Guilan, Qazvin }\end{array}$ & $\begin{array}{l}\text { Ghahari \& Schwarz, } \\
\text { 2012; Aghadokht et } \\
\text { al., 2017; current } \\
\text { study }\end{array}$ \\
\hline 142 & Vulgichneumon saturatorius Linnaeus, 1758 & Guilan, Lorestan & $\begin{array}{l}\text { Heinrich, 1929; } \\
\text { Ghahari \& Gadalla, } \\
\text { 2015, current study }\end{array}$ \\
\hline 143 & Vulgichneumon suavis Gravenhorst, 1820 & $\begin{array}{l}\text { Golestan, Guilan, } \\
\text { Ardabil }\end{array}$ & $\begin{array}{l}\text { Heinrich, 1929; } \\
\text { Kolarov \& Ghahari, } \\
\text { 2008; Aghadokht et } \\
\text { al., 2017; current } \\
\text { study }\end{array}$ \\
\hline
\end{tabular}

* New species for science; ${ }^{* *}$ New record for the Iranian insect fauna; ${ }^{* * *}$ New provincial record.

\section{Acknowledgments}

We thank the Department of Entomology, Tarbiat Modares University for providing financial support for this study. We are also grateful to Dr Mohammad Khayrandish for helping us with the collecting of the specimens.

\section{Conflict of Interests}

The authors declare that there is no conflict of interest regarding the publication of this paper.

\section{ORCID}

Ali Asghar Talebi: https:/ / orcid.org/0000-0001-5749-6391

Matthias Reidel: https:// orcid.org/0000-0002-1927-7347

Hamidreza Hajiqanbar: https:/ / orcid.org/0000-0001-9788-5375 


\section{References}

Aghadokht, P. A., Diller, E., Fekrat, L., Rakhshani, E., \& Nadimi, A. (2017) A survey on the tribes Phaeogenini and Platylabini (Ichneumonidae: Ichneumoninae) with two generic records for the fauna of Iran. Iranian Journal of Animal Biosystematics, 13 (2), 207-219. https://doi.org/10.22067/ijab.v13i2.67753

Amiri, A., Talebi, A.A., Riedel, M., Rakhshani, E. \& Hajiqanbar, H. (2015a) A survey of Metopiinae (Hymenoptera: Ichneumonidae) in southern Iran, with three new records. Journal of Crop Protection, 4 (4), 519-531.

Amiri, A., Talebi, A.A., Jussila, R., Rakhshani, E. \& Hajiqanbar, H. (2015b) A study of the Iranian Cremastinae (Hymenoptera: Ichneumonidae). Journal of Insect Biodiversity and Systematics, 1 (2), 87-100.

Amiri A., Talebi, A.A., Jussila, R., Rakhshani, E. \& Hajiqanbar, H. (2016a) Study of the subfamily Ophioninae (Hymenoptera: Ichneumonidae) in southern Iran. Journal of Entomological Society of Iran, 35 (4), 53-67.

Amiri, A., Talebi, A.A., Castillo, C.R., Rakhshani, E. \& Hajiqanbar, H. (2016b) Study of the genus Lissonota (Hymenoptera: Ichneumonidae: Banchinae) in southern Iran. Journal of Entomological Society of Iran, 36 (2), 89-99.

Amiri, A., Talebi, A.A., Rakhshani, E. \& Hajiqanbar, H. (2017) First report of the genus Cymodusa (Ichneumonidae: Campopleginae) from Iran. Journal of Insect Biodiversity and Systematics, 3 (2), 81-89.

Barahoei, H., Rakhshani, E. \& Riedel, M. (2012) A checklist of Ichneumonidae (Hymenoptera: Ichneumonoidea) from Iran. Iranian Journal of Animal Biosystematics, 8, 83-133.

Barahoei, H., Rakhshani, E., Kasparyan, D.R., Schwarz, M. \& Riedel, M. (2013) Contribution on the knowledge of Ichneumonidae (Hymenoptera) in the northern part of Sistan-o-Baluchestan province, Iran. Acta Zoologica Bulgarica, 65 (1), 131-135.

Barahoei, H., Fathabadi, K., Rakhshani, E., \& Dozhanga, A. (2014a) Study on Ichneumonidae (Hymenoptera) in Khorasan-e-Razavi province, Eastern part of Iran. The 1st National Conference on Stable Agriculture and Natural Resources, Tehran, Iran, vol. 1, pp. 1-7.

Barahoei, H., Moradpour, H., Rakhshani, E., \& Sharifi, Z. (2014b) Ichneumonidae (Hymenoptera) fauna on Alfalfa field in Khorasan-e-Razavi Province. The 1st National Conference on Stable Agriculture and Natural Resources, Tehran, Iran, vol. 1, pp. 1-5.

Barahoei, H., Nader, E., \& Rakhshani, E. (2015) A survey on Ichneumonidae of Isfahan province, central Iran. Journal of Crop Protection, 4 (2), 157-166.

Broad, G.R., Shaw, M.R. \& Fitton, M.G. (2018) Ichneumonid Wasps (Hymenoptera: Ichneumonidae): their Classification and Biology. RES Handbooks for the Identification of British Insects Volume 7 Part 12, Royal Entomological Society, London, UK, 418pp.

Burks, B.D. \& Hurd, P.D. (1979) Catalog of Hymenoptera in America North of Mexico. Smithsonian Institution Press. Washington, D.C.

Darvishnia, H., Esmaeili, H.R., Sadeghi, S., Riedel, M. \& Mohammadi-Khoramabadi, A. (2018) Exephanes tauricus Hinz, 2000 (Hymenoptera: Ichneumonidae): a new record to Iranian fauna. Biharean Biologist, 12 (1), 51-52.

Falahatpisheh, A., Fallahzadeh, M., Mohammadi-Khoramabadi, A., Jussila, R. \& Dousti, A.F. (2021) Additions to the Iranian fauna of Ichneumonidae (Hymenoptera: Ichneumonoidea) with first records of two genera and 13 species. Journal of Insect Biodiversity and Systematics, 7 (2), 145-157.

Ghadiri Rad, S., Ebrahimi, E. \& Akbarpoor, A. (2007) Report of two parasitoid wasps on Helicoverpa armigera (Lep.: Noctuidae) from Iran. Journal of Entomological Society of Iran, 26 (2), 93-94. 
Ghahari, H., \& Schwarz, M. (2012) A study of the Ichneumonidae (Hymenoptera: Ichneumonoidea) from the Qazvin province, Iran. Linzer Biologische Beiträge, 44 (1), 855-862.

Ghahari, H. \& Gadallah, N.S. (2015) A study on the ichneumonid wasps (Hymenoptera: Ichneumonidae) from the province of Lorestan, Iran. Arquivos Entomoloxicos, 13, 329-338. https://doi.org/10.21248/contrib.entomoL66.1.119-124

Ghahari, H. \& Jussila, R. (2010a) A contribution to the Ichneumon wasps (Hymenoptera: Ichneumonidae) from Golestan National Park and vicinity, northeastern Iran. Linzer Biologische Beiträge, 42 (2), 1379-1384.

Ghahari, H. \& Jussila, R. (2010b) Some new records of Iranian Ichneumoninae (Hymenoptera: Ichneumonidae). Linzer Biologische Beiträge, 42 (2), 1373-1377.

Ghahari, H., Schwarz, M. (2011) A contribution to the knowledge of ichneumonid wasps from Mazandaran province, northern Iran (Hymenoptera, Ichneumonidae). Spixiana, 34 (2), 195-198.

Ghahari, H. \& Jussila, R. (2011a) A contribution to the knowledge of Ichneumon wasps (Hymenoptera: Ichneumonoidea: Ichneumonidae) from Azerbaijan-e-Gharbi Province, Northwestern Iran. Linzer Biologische Beiträge, 43 (2), 1277-1284.

Ghahari, H. \& Jussila, R. (2011b) A study on the ichneumonid wasps (Hymenoptera: Ichneumonidae) from some regions of Iran. Linzer Biologische Beiträge, 43 (1), 753-758.

Ghahari, H. \& Jussila, R. (2011c) Five species of Ichneumonidae (Hymenoptera) new to Iran. Zoology in the Middle East, 52, 123-124. https:// doi.org/10.1080/09397140.2011.10638490

Ghahari, H. \& Jussila, R. (2014) A faunistic study on the Ichneumonidae (Hymenoptera: Ichneumonoidea) from the west of Iran. Linzer Biologische Beiträge, 46 (2), 1373-1377.

Ghahari, H. and Jussila, R. (2016) Contribution to the knowledge of the fauna of Ichneumonidae (Hymenoptera: Ichneumonoidea) from Iran. Beiträge zur Entomologie, 66 (1), 119-124. https://doi.org/10.21248/contrib.entomol.66.1.119-124

Habibi-Badrabadi, S., Khayrandish, M., \& Mohammadi-Khoramabadi, A. (2018) Faunistic Survey and Species Diversity of Parasitoid Wasps of Pimpiliformes and Ichneumoniformes Groups (Hymenoptera: Ichneumonidae) in Yazd Province, Iran. Taxonomy and Biosystematics, 9 (32), 120. https://doi.org/10.22108/tbj.2018.105845.1034

Hasanshahi, G., Abbasipour, H., Jussila, R. \& Jahan, F. (2014) First report of Barichneumon derogator (Hym.: Ichneumonidae: Ichneumoninae) from Iran. Journal of Entomological Society of Iran, 34 (2), 9-10.

Hedwig, K. (1957) Ichneumoniden Und Braconiden aus den Iran 1954 (Hymenoptera). Jahresheft des Vereins fur Vaterlaendische Naturkunde, 112 (1), 103-117.

Heinrich, G.H. (1929) Beiträge zur Kenntnis der Insektenfauna Nordpersiens. Nach der Ausbeute der Elbrus-Expedition von G. Heinrich und Dr. M. Dammholz Anno 1927. Ichneumonidae (Hym.). Deutsche Entomologische Zeitschrift, 1929, 305-326. https:/ / doi.org/10.1002/mmnd.48019290410

Heinrich, G.H. (1978) Eastern Palaearctic hymenopterous insects of the subfamily Ichneumoninae (In Russian). Leningrad, $81 \mathrm{pp}$.

Hooshyar, H., Vafaei-Shoshtari, R., Mohammadi-Khoramabadi, A., Goldasteh, S., Sanatgar, E. \& Jussila, R. (2019) Study of the subfamilies Cryptinae and Ichneumoninae (Hymenoptera: Ichneumonidae) from Mazandaran province, with records of five species new to Iran. Journal of Entomological Research, 11 (2), 11-32.

Jeong, J.C., Cha, J.Y., Choi, J.K. \& Lee, J.W. (2009) Six Species of the Tribe Ichneumonini (Hymenoptera: Ichneumonidae) New to Korea. Korean Journal of Systematic Zoology, 25 (1), 107119. https://doi.org/10.5635/KJSZ.2009.25.1.107

Kolarov, J. \& Ghahari, H. (2008) A study of the Iranian Ichneumonidae (Hymenoptera) III. Ichneumoninae. Acta Entomologica Serbica, 13 (1/2), 61-76. 
Masnadi, A. \& Jussila, R. (2008) Contribution to the knowledge of ichneumonid wasps of Iran. Subfamilies Ichneumoninae, Pimplinae and Diplazontinae (Hymenoptera, Ichneumonidae). Entomofauna, 29 (22), 293-320.

Mahyabadi, M., Khayrandish, M., \& Takalloozadeh, H. (2018) Species diversity of parasitoid wasps of Ichneumoniformes (Hymenoptera: Ichneumonidae) in Jiroft county, Kerman province, Iran. Applied Entomology and Phytopathology, 85 (2), 191-202.

Mohammadi-Khoramabadi, A., Talebi, A.A. \& Farahani, S. (2011) Hybrizon buccatus (de Brebisson, 1825), the first record of the subfamily Hybrizontinae (Hymenoptera: Ichneumonidae) from northern Iran. Biharean Biologist, 5, 162-163.

Mohammadi-Khoramabadi, A., Talebi, A.A. \& Zwakhals, K. (2013a) A study of the subfamily Pimplinae (Hymenoptera: Ichneumonidae) in the north of Iran, with eleven new species records. Entomofauna, 34 (2), 29-56.

Mohammadi-Khoramabadi, A., Talebi, A.A. \& Zwakhals, K. (2013b) Study on Diplazontinae (Hymenoptera: Ichneumonidae) in the north central of Iran. Journal of Crop Protection, 2, 241-261.

Mohebban, S., Takalloozadeh, H., Barahoei, H. \& Madjdzadeh, M. (2015) New records of Cryptinae and Ichneumoninae (Hymenoptera: Ichneumonidae) species from Kerman province, Southeast Iran. Journal of Crop Protection, 4 (3), 337-349.

Mohebban, S., Barahoei, H., Takalloozadeh, H.M., Madjdzadeh, S.M. \& Riedel, M. (2016) A survey of the Ichneumonidae (Hymenoptera, Ichneumonoidea) of Kerman province, south-east Iran. Journal of Insect Biodiversity and Systematics, 2 (4), 419-437.

Mojeni, T.D. \& Sedivy, J. (2001) New report of parasitoid ichneumonid wasps of cotton bollworm Helicoverpa armigera (Hub.) (Lep. Noctuidae) in Iran. Journal of Entomological Society of Iran, 21 (1), 107-108.

Rasnitsyn, A.P. \& Sityan, U.W. (1981) [Subfamily Ichneumoninae] - In: Kasparyan, D.R. (ed.) [Keys of the insects of the European part of USSR. Tom.III Hymenoptera Pars 3] in Russian. Leningrad, pp. 506-636.

Riedel, M. (2020) Contribution to the taxonomy of the West Palaearctic Ichneumoninae (Hymenoptera: Ichneumonidae). Mitteilungen der Münchner Entomologischen Gesellschaft, 110, 107-117

Riedel, M., Çoruh, S. \& Özbek, H. (2010) Contribution to the Ichneumoninae (Hymenoptera, Ichneumonidae) fauna of Turkey, with the description of three new species. Türkiye Entomoloji Dergisi, 34 (2), 133-156.

Riedel, M. \& Aghadokht, P. (2017) Contribution to the Ichneumoninae (Hymenoptera, Ichneumonidae) of Iran, with descriptions of three new species. Zoology of the Middle East, 63 (4), 348-355. https:// doi.org/10.1080/09397140.2017.1361190

Riedel, M., Ameri, A., Talebi, A.A. \& Ebrahimi, E. (2019) Contribution to the Ichneumonidae (Hymenoptera) of Iran, with description of seven new species. Linzer Biologische Beiträge, 51 (1), 361-390.

Sarafi, T., Barahoei, H., Madjdzadeh, S.M., \& Askari Hesni, M. (2015) Contribution to the knowledge of the Ichneumonidae (Hym.: Ichneumonoidea) from Neyriz county of Fars province, Iran. Journal of Crop Protection, 4 (Supplementary), 643-653.

Šedivý, J. (1965) Prispevek k poznani hostitelu lumku I. Zprávy Československé Společnosti Entomologické pri CSAV, 1, 6-13. [in Czech]

Selfa, J. (1996) The spanish Ichneumoninae of the Forschungsinstitut and Naturmuseum Senckenberg in Frankfurt (Hymenoptera, Ichneumonidae). Linzer Biologische Beiträge, 28 (1), 177-195. 
Shirzadegan, F., Talebi. A.A., Riedel, M. \& Hajiqanbar, H. (2018) Study of the tribe Heresiarchini (Hymenoptera: Ichneumonidae, Ichneumoninae) in northern Iran, with a new record for the Middle East. Journal of Insect Biodiversity and Systematics, 4 (2), 113-122.

Tereshkin, A.M. (2004) Illustrated key to the Western Palaearctic genera of the subtribe Cratichneumonina (sensu Heinrich). Taxonomic notes on European species of Rugosculpta Heinrich, 1967 (Hymenoptera, Ichneumonidae, Ichneumoninae, Ichneumonini). Russian Entomological Journal, 13 (4), 277-293.

Tereshkin, A.M. (2009) Illustrated key to the Ichneumoninae tribes and Platylabini genera of world fauna (Hymenoptera, Ichneumonidae, Ichneumoninae). Linzer Biologische Beiträge, 41 (2), 13171608.

Tereshkin, A.M. (2011) Illustrated key to the genera of the subtribe Amblytelina of Palaearctic (Hymenoptera, Ichneumonidae, Ichneumoninae, Ichneumonini). Linzer Biologische Beiträge, 43 (1), 597-711.

van Achterberg, C. (2009) Can Townes type Malaise traps be improved? Some recent developments. Entomologische Berichten, 69, 129-135.

Wahl, D.B., Mason, W.R.M. \& Townes, H. (1995) The family-group names of the Ichneumoninae (Hymenoptera: Ichneumonidae). Journal of Hymenoptera Research, 4, 285-293.

Yu, D., van Achterberg, C., \& Horstmann, K. (2016) Taxapad 2016 - World Ichneumonoidea 2015. Taxonomy, Biology, Morphology and Distribution. On USB flash drive. Nepean, Ontario, Canada.

Zardouei Heydari, M., Rakhshani, E. \& Mokhtari, A. (2019) Occurrence of the genus Erigorgus Forster (Hym., Ichneumonidae, Anomaloninae) in Eastern part of Iran with key to species. Journal of Insect Biodiversity and Systematics, 5 (1), 69-78.

Zardouei Heydari M., Rakhshani E., Mokhtari A. \& Schwarz M. (2020a) The genus Anomalon Panzer (Hymenoptera: Ichneumonidae: Anomaloninae) of Iran, with description of a new species. European Journal of Taxonomy 662, 1-19. https:/ / doi.org/10.5852/ ejt.2020.662

Zardouei Heydari, M., Rakhshani, E., Mokhtari, A. \& Schwarz, M. (2020b) New data on the genus Latibulus Gistel, 1848 (Hym., Ichneumonidae, Cryptinae, Cryptini) in Iran. Journal of Insect Biodiversity and Systematics, 6 (2), 157-165.

Zardouei Heydari, M. Z., Rakhshani, E., Rousse, P., Mokhtari, A., \& Schwarz, M. (2020c) A new species of Pristomerus Curtis, 1836 (Hymenoptera, Ichneumonidae, Cremastinae) and key to the known species in Iran. Zootaxa, 4809 (1), 187-194. https:/ / doi.org/10.11646/zootaxa.4809.1.12

Zardouei Heydari, M., Rakhshani, E., Mokhtari, A. \& Schwarz, M. (2020d) A faunistic overview of Temelucha Förster (Hym., Ichneumonidae, Cremastinae) in Iran. Turkish Journal of Zoology, 44, 355-374. https:// doi.org/10.3906/zoo-1912-42

Zarepour, A.R., Talebi, A.A. \& Loni, S. (2008) Fauna of Ichneumonid wasps from Yazd, Iran. Journal of Entomological Research, 2 (1), 13-20.

Zarepour, A.R., Talebi, A.A., Vafaei Shoushtari, R. (2009) Three new species records of Ichneumonid wasps, (Hym., Ichneumonidae) from Yazd, Iran. Journal of Entomological Research, 1 (1), 67-77. 
تونه جديد و كَزارشهاى جديد از قبيله Hymenoptera: Ichneumonidae, ) Ichenumonini (Ichneumoninae

$$
\begin{aligned}
& \text { فريد شيرزادَّان'، على اصغر طالبى '“. ماتياس ريدل 'و حميدرضا حاجىقنبر' } \\
& \text { ا گروه حشرهشناسى، دانشكده كشاورزى، دانشآه تربيت مدرس، تهران، ايران. }
\end{aligned}
$$

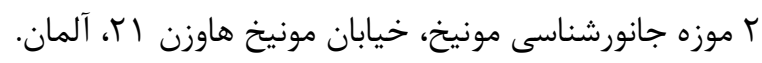

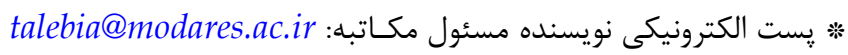

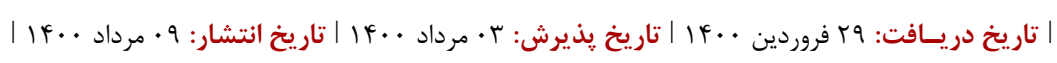

Ichneumonidae: ) Ichneumonini Latreille, جكيـده: فون قبيله 1802 (Ichneumoninae

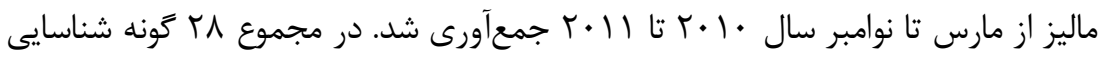

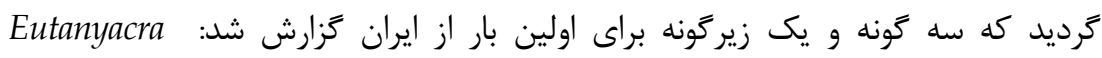
Ichneumon quadrialbatus Gravenhorst, 1820 ،ruficornis Berthoumieu, 1894 Stenobarichneumon, Ichneumon sarcitorius turkestanicus Heinrich, 1929

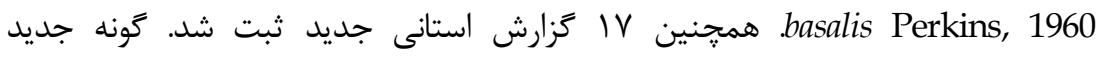
Anisopygus persicus Shirzadegan, Talebi \& Riedel sp. nov. شمال ايران توصيف شد. تعداد كونهاى شناخته شده قبيله Ichneumonini در ايران به

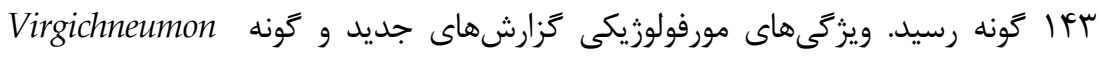
Ichneumonini و همجنين ليست بلمروزشده قبيله

$$
\text { از ايران ارايه شد. }
$$

وازَّـان كليدى: كَزارش جديد، كَونه جديد، Ichneumoninae،

$$
\text { ردهبندى، جكليست، يراكنش، ايران كئن }
$$

